\title{
Effects of Proctolin on Contractions, Membrane Resistance, and Non-Voltage-Dependent Sarcolemmal Ion Channels in Crustacean Muscle Fibers
}

\author{
Christian F. J. Erxleben, ${ }^{1}$ Amedeo deSantis, ${ }^{2}$ and Werner Rathmayer ${ }^{1}$ \\ 'Department of Biology, University of Konstanz, D-78434 Konstanz, Germany and 'Stazione Zoologica "Anton \\ Dohrn," Villa Comunale, I-80121 Napoli, Italy
}

The neuropeptide proctolin in nanomolar concentrations enhances the contraction of crustacean muscle fibers manyfold. The cellular mechanisms underlying this potentiation were investigated in single, isolated, fast-contracting abdominal extensor muscle fibers of a small crustacean, the marine isopod /dotea baltica.

Force measurements and current-clamp experiments revealed two actions of proctolin on the muscle fibers. In half of the preparations, proctolin $\left(10^{-9}-10^{-6} \mathrm{~m}\right)$ increased the fiber's input resistance by up to $25 \%$. In about one-fourth of the preparations, proctolin induced all-or-none action potentials in response to depolarizing current pulses in muscle fibers that showed graded electric responses under control conditions. In both cases, proctolin potentiated the peak force of muscle contractions (between 1.5- and 18fold for $5 \times 10^{-9} \mathrm{M}$ proctolin). Proctolin affected neither the membrane resting potential nor the threshold for excitation-contraction coupling.

Using cell-attached patches on the sarcolemmal membrane, we identified non-voltage-dependent ion channels which contribute to the passive membrane properties of the muscle fibers. $A 53 \pm 6$ pS channel had its reversal potential near rest and carried outward current at depolarized potentials with physiological saline in the recording pipette. With isotonic $\mathrm{K}^{+}$saline in the patch pipette, the reversal potential was $+85 \pm 12 \mathrm{mV}$ depolarized from the resting potential and single-channel conductances ranged from 36 to $166 \mathrm{pS}$. Proctolin modulated the activity of all these putative $\mathrm{K}^{+}$channels by reducing the number of functionally active channels.

The effects of proctolin on force of contraction, input resistance, and single-channel activity were mimicked by a membrane-permeating analog of cAMP. Conversely, a monothio analog of cAMP (Rp-cAMPS), a blocker of protein kinase $A$ activity, substantially decreased the membrane input resistance of the muscle fibers. The results suggest that activation of the CAMP signal pathway and phosphorylation of non-voltage-dependent $\mathrm{K}^{+}$channels by protein

Received Sept. 6, 1994; revised Nov. 28, 1994; accepted Dec. 7, 1994

This work was supported by the DFG, SFB 156. We thank Ms. M. A. Cahill for editorial assistance, Ms. C. Giehle for Figure 1, and Mr. D. Ruhrmann for his excellent technical assistance.

Correspondence should be addressed to Christian F. I. Frxleben at the above address.

Copyright @ 1995 Society for Neuroscience 0270-6474/95/154356-14\$05.00/0 kinase $A$ are involved in the potentiation of contractions by proctolin in the muscle fibers of this crustacean.

[Key words: Crustacea, Idotea, neuropeptides, potassium channel modulation, cAMP, muscle contraction]

The penta-peptide proctolin (H-Arg-Tyr-Leu-Pro-Thr- $\mathrm{NH}_{2}$ ) was originally isolated as "gut-factor" from the cockroach Periplaneta americana (Brown, 1967). Subsequently, its presence was demonstrated in neurons of a number of arthropods, mainly crustaceans and insects (e.g., Bishop et al., 1984; Siwicki et al., 1985; Marder et al., 1986; Siwicki and Bishop, 1986; Stangier et al., 1986; Beltz et al., 1990; Orchard, 1989 for review on insects). In motorneurons, it is thought to coexist with the excitatory transmitter glutamate (Witten and O'Shea, 1985; Bishop et al., 1987; Bartos et al., 1994). In crustaceans, proctolin in nanomolar concentrations excites premotor and motor neurons of the cardiac ganglion (Sullivan and Miller, 1984) and pyloric cells of the stomatogastric ganglion of the lobster (Nusbaum and Marder, 1989), evoking action potentials and modulating their rhythmic discharge patterns.

Proctolin also evokes tonic contractions in skeletal and visceral muscles of insects and crustaceans and modulates the efficiency of their neuromuscular transmission. The amplitude of neurally evoked contractions is cnhanced by pre- and/or postsynaptic action of the peptide (crustacean skeletal muscle: Schwarz et al., 1980; Bishop et al., 1984; Mercier and Wilkens, 1985; Pasztor and Golas, 1993; insect hyponeural, skeletal, and visceral muscle: Cook and Holman, 1980, 1985; Evans, 1984; Hertel et al., 1985; Hertel and Penzlin, 1986; Baines et al., 1990; Bauer, 1991; Limulus heart and skeletal muscle: Benson et al., 1981; Watson et al., 1983; Rane et al., 1984; Walson and Hoshi, 1985).

The cellular mechanisms underlying this modulatory action of proctolin are largely unknown. In crustacean neurons, a proctolin-induced depolarization was shown to result from activation of an inward current, carried mainly by sodium (Freschi, 1989; Golowasch and Marder, 1992). In muscle fibers, however, the enhancement of contractions by proctolin is not accompanied by depolarizations (Bishop et al., 1987). Effects on ionic currents were deduced indirectly from changes in muscle fiber input resistance or active membrane responses (Miller and Sullivan, 1981; Adams and O'Shea, 1983; Sullivan and Miller, 1984; Hertel and Penzlin, 1986). With the exception of one study on $\mathrm{Ca}^{2+}$ permeable channels of tonic flexor muscles in crayfish (Bishop et al., 1991a), direct evidence for the modulation of single ion channels by proctolin is also lacking. 
The effects of proctolin are thought to be mediated by intracellular signaling pathways, the cAMP cascade, and/or phosphoinositides. The myogenic rhythm of a bundle of slow fibers of the locust's extensor tibiae is enhanced by a cAMP increase via stimulation of a proctolin-sensitive adenylate cyclase (Evans, 1984; Swales and Evans, 1988). Likewise, the proctolin-induced increase in $\mathrm{Ca}^{2+}$ channel activity in crayfish muscle seems to be mediated by an increase in cAMP (Bishop et al., 1991a). However, sustained contractions caused by proctolin in the dactyl opener muscle of the lobster (Schwarz et al., 1980) are not accompanied by a detectable increase in cAMP levels or protein phosphorylation (Goy et al., 1984). The potentiating effect of proctolin on neurally evoked contractions of the locust's mandibular muscles is mimicked by inositol 1,4,5-trisphosphate $\left(\mathrm{IP}_{3}\right)$ and phorbol esters, suggesting stimulation of the phosphoinositide pathway by the peptide (Baines et al., 1990; Baines and Downer, 1992).

To date, most investigations of the effects of proctolin on muscle contraction employed whole muscles. Most arthropod muscles, however, are composed of fibers of different physiological types (e.g., Jahromi and Atwood, 1969; Rathmayer and Maier, 1987) which may differ in their susceptibility to peptidergic modulation. For this reason, we have developed a single fiber preparation. We describe the effects of proctolin on contractions of single muscle fibers and their voltage-current relationship, and provide evidence that the observed input resistance increase is due to the closure of a population of non-voltagedependent $\mathrm{K}^{+}$channels. In Idotea, the proctolin effects seem to be mediated by the cAMP pathway and protein kinase A.

Some of the results have been published in abstract form (Erxleben and Rathmayer, 1992).

\section{Materials and Methods}

Preparation and solutions. Experiments were performed on single fibers of the abdominal extensor muscles of the marine isopod Idotea baltica. Specimens were collected in the gulf of Naples and kept in tanks with sea water at either ambient temperature (Naples) or $16^{\circ} \mathrm{C}$ (Konstanz). A schematic drawing of the animal's dorsal aspect is shown in Figure 1. The abdominal extensor musculature of the posterior abdominal segments consists of eight fibers in each half-segment. Four are confined to the segment, two extend into the anterior, and two come from the posterior segment. Most experiments were performed with the segmental fiber 2 of segments 6 or 7. For current-clamp and contraction measurements, the muscle fibers were stretched to the in situ resting length in a bath of $1 \mathrm{ml}$ volume which allowed rapid exchange of the solutions. Experiments were carried out either at room temperature (patch-clamp experiments) or in a temperature-controlled bath at $18^{\circ} \mathrm{C}$ (current-clamp and contraction measurements) in artificial sea water (ASW) with (mM) $490 \mathrm{NaCl}, 8 \mathrm{KCl}, 10 \mathrm{CaCl}_{2}, 12 \mathrm{MgCl}_{2}$, and 20 Tris(hydroxymethyl)aminomethan (TRIS), $\mathrm{pH} 7.4$. Proctolin (Sigma) was applied by bath application through a pipette (patch-clamp experiments) or bath solution exchange (current-clamp and contraction measurements). Adenosine 3', 5 '-monophosphothioate-Rp (Rp-cAMPS) was obtained through Calbiochem-Novabiochem.

Electrophysiological techniques. Standard electrophysiological techniques were used for potential recordings and current injection. The input resistance of the muscle fibers was determined from the slope of the linear part of the V-I curve for small $(\leq 30 \mathrm{mV})$ hyperpolarizations and depolarizations. Current- and potential-recording electrodes were inserted within one fiber diameter of each other $(\sim 150 \mu \mathrm{m})$, approximately in the middle of the muscle fiber. The length constant was in the order of $300 \mu \mathrm{m}$, precluding effective voltage control over the whole fiber. Amplifiers for potential recordings and current injection were designed and built by the electronics workshop of the University of Konstanz. For better current-passing properties, electrodes were filled with a 1:1 mixture of $3 \mathrm{M} \mathrm{KCl}$ and potassium citrate. Electrodes had a DC resistance between 5 and $10 \mathrm{M} \Omega$ The contraction force of single muscle fibers was measured with a small isometric transducer (KG3, Scientific
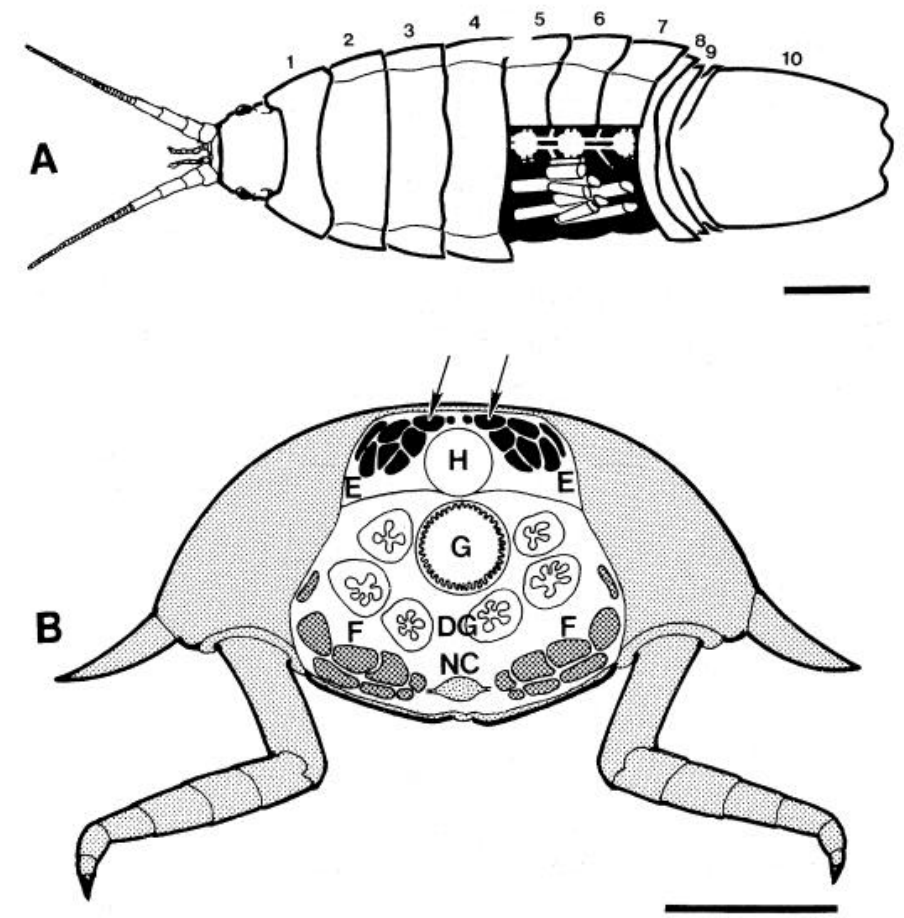

Figure 1. Drawing of the marine isopod Idotea baltica. A, Dorsal view in which half of the tergites of segments 5-7 have been removed, showing the ventral nerve cord and the position of the extensor muscle fibers for the sixth abdominal segment. (Muscles and nerve cord not to scale.) $B$, Cross section in the region of the sixth abdominal segment showing the arrangement of the eight extensor muscle fibers $(E)$ on each side. Arrows mark fibers number 2 , on which the experiments were carried out. $F$, flexor muscles; $H$, heart; $G$, gut; $D G$, digestive glands; $N C$, ventral nerve cord. Intrinsic and extrinsic leg muscles not shown. Calibration bars are $2 \mathrm{~mm}(A)$ and $1 \mathrm{~mm}(B)$.

Instruments $\mathrm{GmbH}$, Heidelberg, Germany) with a maximum sensitivity of $100 \mathrm{mg}$ (full range).

Conventional gigaseal techniques were used for patch clamping, with pipettes made from borosilicate glass (CLARK electromedical instruments, Reading, England) coated with Sylgard 184 elastomer (Dow Corning) to reduce noise. For cell-attached patch-clamp recordings, the electrodes contained slightly hypotonic (with respect to the bath solution) saline of either $90 \% \mathrm{ASW}$ or high $\mathrm{K}^{+}$solution (mM: $400 \mathrm{KCl}, 10$ $\mathrm{CaCl}_{2}, 12 \mathrm{MgCl}_{2}, 20$ HEPES, pH 7.4). To achieve gigaohm seals on the sarcolemmal membrane of the fibers, the preparation was treated with collagenase (Type 1A, Sigma). Five to ten minutes of incubation with $0.5 \mathrm{mg} / \mathrm{ml}$ collagenase at room temperature did not cause the membrane to bleb and was sufficient to get seals of $10-100 \mathrm{G} \Omega$.

Data acquisition and analysis. Membrane potential, current, and force of contraction were recorded, and pulse protocols for the current stimuli were controlled by a data acquisition interface (CED1401, CED, Cambridge, England) connected to an IBM PC-compatible computer. Data were analyzed with software of the CED patch and voltage-clamp suite. The same interface and software were used for patch-clamp recordings. Single-channel currents were recorded with an EPC-7 (List Electronic, Darmstadt, Germany) amplifier and, for analysis, low-pass filtered usually at $3 \mathrm{kHz}$ and digitized at five times the filter frequency. In the case of recordings with hypotonic ASW in the patch pipette, single-channel conductances $(\gamma)$ were determined from the linear part of the I-V relationship of outward $\mathrm{K}^{+}$currents. With high $\mathrm{K}^{+}$saline in the pipette, $\gamma$ was determined from the $\mathrm{I}-\mathrm{V}$ relationship of inward $\mathrm{K}^{+}$ currents. Reversal potentials were determined either directly from the I-V relationships or, in some experiments, by voltage ramps in which the potential applied to the patch pipette was stepped to $-100 \mathrm{mV}$ (from the resting potential) and then linearly increased to $+100 \mathrm{mV}$ within $0.5 \mathrm{sec}$. Steady state open probabilities $\left(\mathrm{P}_{\mathrm{o}}\right)$ were determined by summation of open times during 4-30 sec of activity (depending on the opening frequency of the channels). Alternatively, in particular for patches with a large number of channels $(\geq 5)$, amplitude histograms of 
A control

Tension
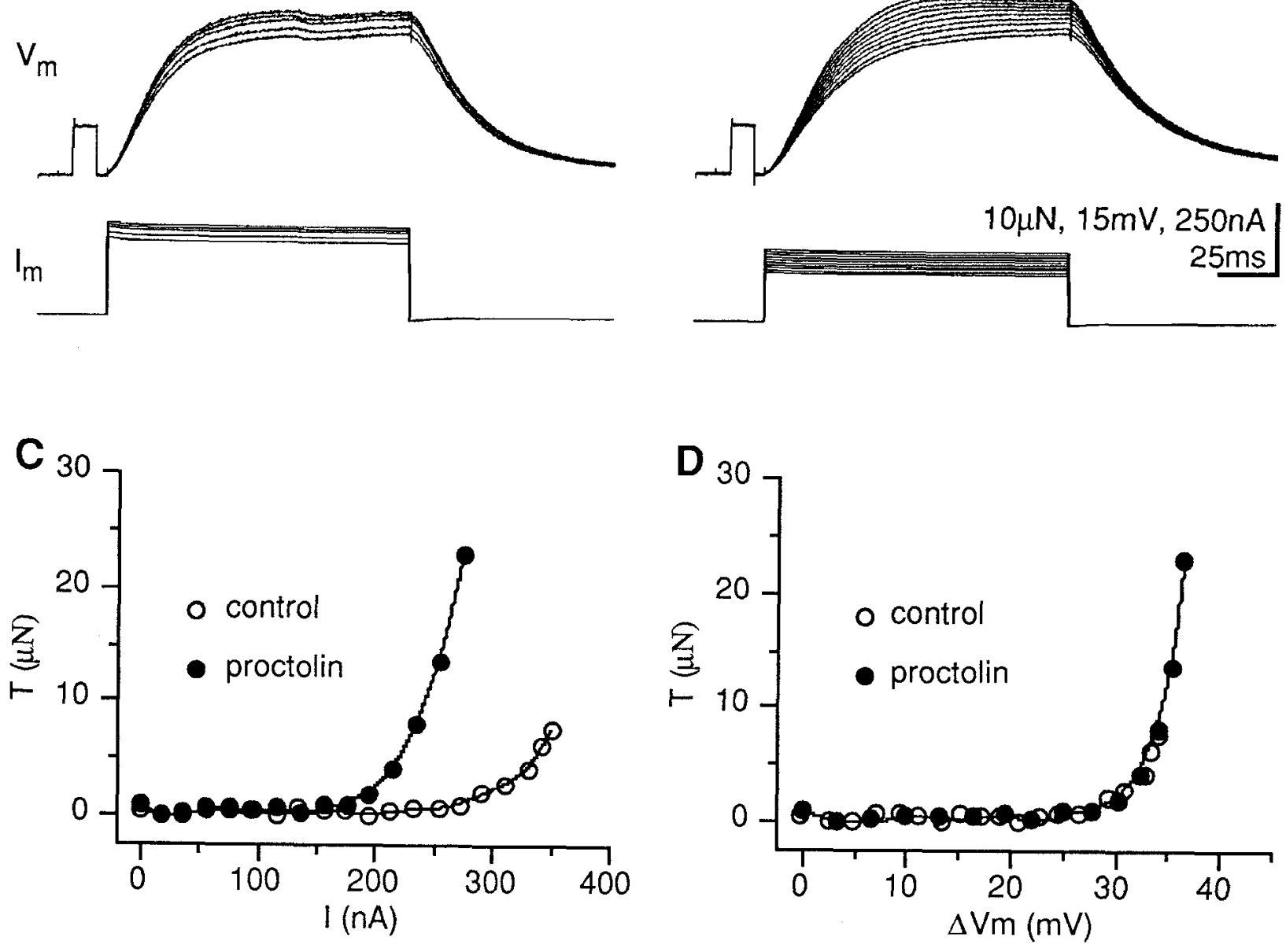

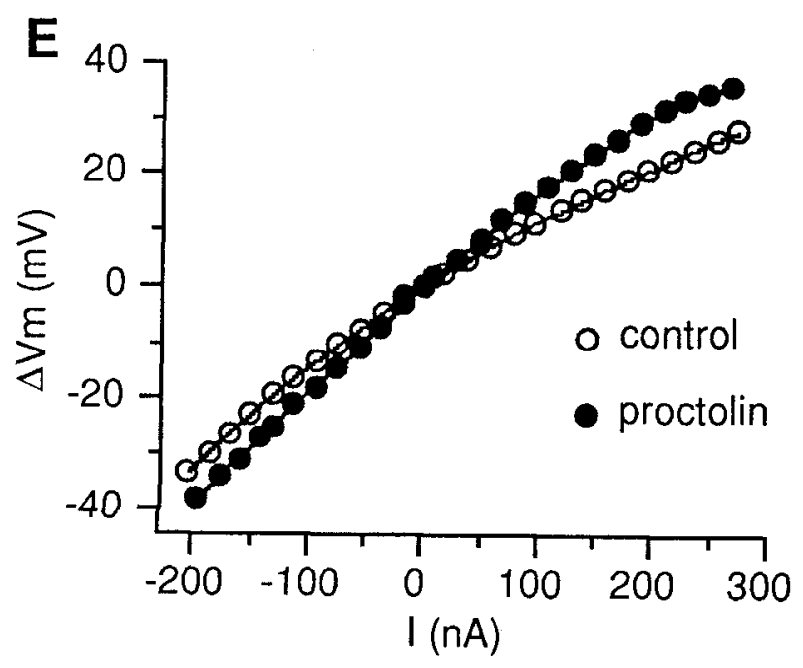




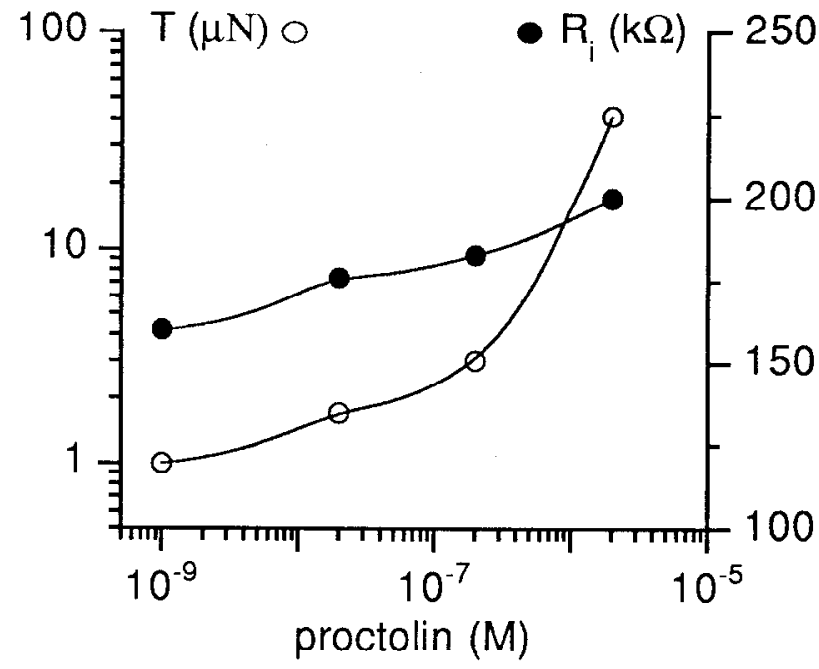

Figure 3. The effect of proctolin on input resistance and contraction amplitude is dose dependent. Plot of peak contraction amplitude and input resistance as a function of the proctolin concentration in the bath. Membrane resting potential $-74 \pm 1 \mathrm{mV}$ throughout the experiment.

all data points were constructed. Relative open probabilities were then obtained by subtracting the integrals of experimental histograms from control histograms of equal sample duration (10-35 sec). Downward deflections of the single-channel current traces correspond to inward currents. For cell-attached patches, holding potentials are relative to the cell's resting membrane potential and absolute potentials for the excised patches. Changes in the holding potential are always expressed as cytoplasmic side relative to the exterior face of the membrane as in conventional intracellular recordings. Pooled data are presented as mean and standard deviation of the mean (SD).

\section{Results}

Proctolin potentiates contractions and increases the input resistance of muscle fibers

The abdominal extensor muscles from the marine isopod Idotea baltica are ideally suited for single fiber preparations because they consist of only eight easily identifiable fibers in each halfsegment. These fibers exhibit high myofibrillar ATPase activity, which is characteristic of fibers with a high shortening velocity (Galler and Rathmayer, 1992). Muscle fiber 2 of the sixth abdominal segment, which was used in most experiments, is approximately $1000 \mu \mathrm{m}$ long and $150 \mu \mathrm{m}$ in diameter. The average resting potential of the fibers is $-70 \pm 5 \mathrm{mV}$ (SD, $n=24$ ). Intracellular current injection resulted in graded depolarizations, which in most fibers elicited graded active membrane responses (Fig. $2 A$ ) when the fibcr's membrane potential was more positive than $-40 \pm 5 \mathrm{mV}$ (SD, $n=14$ ). Only $10 \%$ of the fibers (three of 28 ) responded with all-or-none action potentials. The threshold for a noticeable contraction (E-C threshold) was $-42 \pm 4$ $\mathrm{mV}$ (SD, $n=12$ ). Depolarization beyond E-C threshold resulted in graded contractions proportional to the depolarization in the fibers with graded electrical responses (Fig. 2A,C) and in all-ornone contractions in the fibers producing all-or-none action potentials. The current duration was long-usually $200 \mathrm{msec-}$ compared to the time constant of the fibers, so that passive voltage responses could reach a plateau.

Addition of proctolin $\left(10^{-9}-10^{-6} \mathrm{M}\right.$ final concentration) produced an increase in contraction amplitudes within minutes of application. We found two distinct effects of proctolin on the electrical properties of the muscle fibers: an increase in the fiber's membrane resistance and the conversion of graded electrical responses into all-or-none action potentials. Potentiation of the contraction amplitudes by the peptide were always accompanied by a change in membrane resistance, excitability, or both. Proctolin effects persisted as long as the peptide was present (up to $30 \mathrm{~min}$ were tested).

For most fibers, electric membrane responses remained graded upon addition of proctolin, even with large depolarizations. The contractions also remained graded but increased in amplitude (Fig. 2B,C). The increase in contraction amplitude with proctolin varied widely among preparations (from 1.5 - to 18 -fold for $5 \times$ $10^{-9} \mathrm{M}$ proctolin). The potentiation was, however, dose dependent for a given muscle fiber (Fig. 3). In half of the experiments (seven of 15), the increase in force of contraction with the peptide was accompanied by an increase in the fiber's input resistance, $\mathrm{R}_{\mathrm{i}}$ (Fig. 2E). Again, as noted for the enhancement of contraction, there was considerable variability among preparations, but a dose dependency for a given muscle fiber was always evident (Fig. 3). In one-fourth of the fibers (four of 15), proctolin induced all-or-nothing action potentials and all-ornothing contractions in fibers that responded with both graded electric membrane responses and graded contractions under control conditions (Fig. 4A-C). In two of these fibers, there was no change in input resistance (Fig. $4 D$ ), while an additional increase in input resistance occurred in the other two fibers. The appearance of all-or-none action potentials versus graded electrical response was not dependent on proctolin concentration. Regardless of the type of proctolin response--induction of action potentials or increase of membrane resistance-we never observed a significant change in the resting membrane potential of the muscle fibers in response to proctolin. In addition to the variability noted above, proctolin sometimes failed to exert any effect on either electrical membrane properties or contraction amplitudes. This occurred in series of experiments (not included in the above analysis) during the late summer and winter months, and may indicate a seasonal sensitivity to the peptide (see Discussion).

\section{Identification of voltage-independent $K^{+}$-permeable channels in cell-attached patches}

The fact that the membrane resistance is affected over a wide range of membrane potentials (Fig. $2 E$ ) suggests the closure of non-voltage-dependent ion channels by proctolin. We used hypotonic ASW as well as high $\mathrm{K}^{+}$pipette solutions to identify such channels. High $\mathrm{K}^{+}$solution was used to shift the $\mathrm{K}^{+}$equilibrium potential for the patch to $\sim 0 \mathrm{mV}$; that is, for the cellattached patches $\sim+70 \mathrm{mV}$ depolarized from the fiber's resting potential. This way we could observe current through $\mathrm{K}^{+}$-selective channels near the cell's resting membrane potential without

Figure 2. Proctolin increases muscle tension by increasing the fiber's input resistance. Records of muscle tension from a single fiber, membrane potential, and applied current before $(A)$ and $13 \mathrm{~min}$ after $(B)$ application of $2 \times 10^{-9} \mathrm{M}$ proctolin. $C$, Peak tension plotted as a function of the applied constant current before and after application of proctolin. $D$, Relationship of peak tension (from $A$ ) replotted as function of the membrane depolarization at the end of the $200 \mathrm{msec}$ current pulses. E, Voltage-current relationship before and after application of proctolin. The calibration pulse in the voltage traces (middle traces in $A, B$ ) is $10 \mathrm{mV}, 10 \mathrm{msec}$. Membrane resting potential $-72 \pm 1 \mathrm{mV}$ throughout the experiment. 
A control

Tension
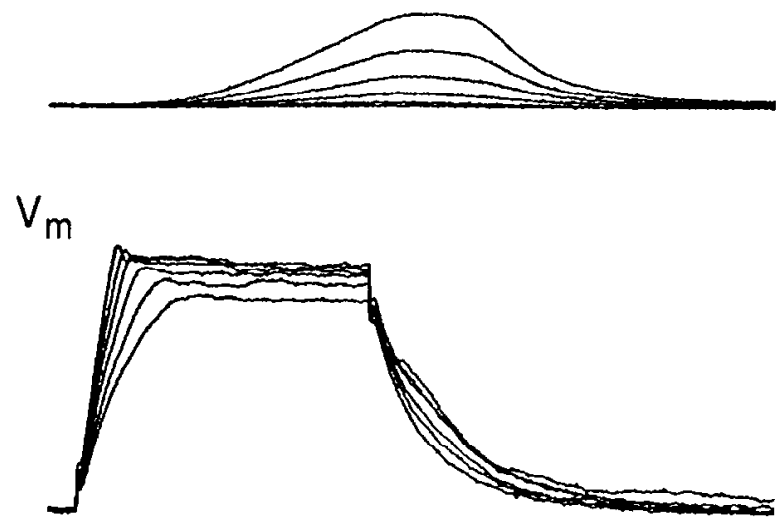

$I_{m}$

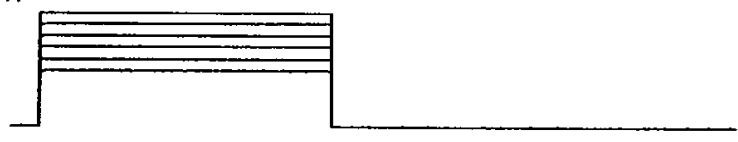

B proctolin
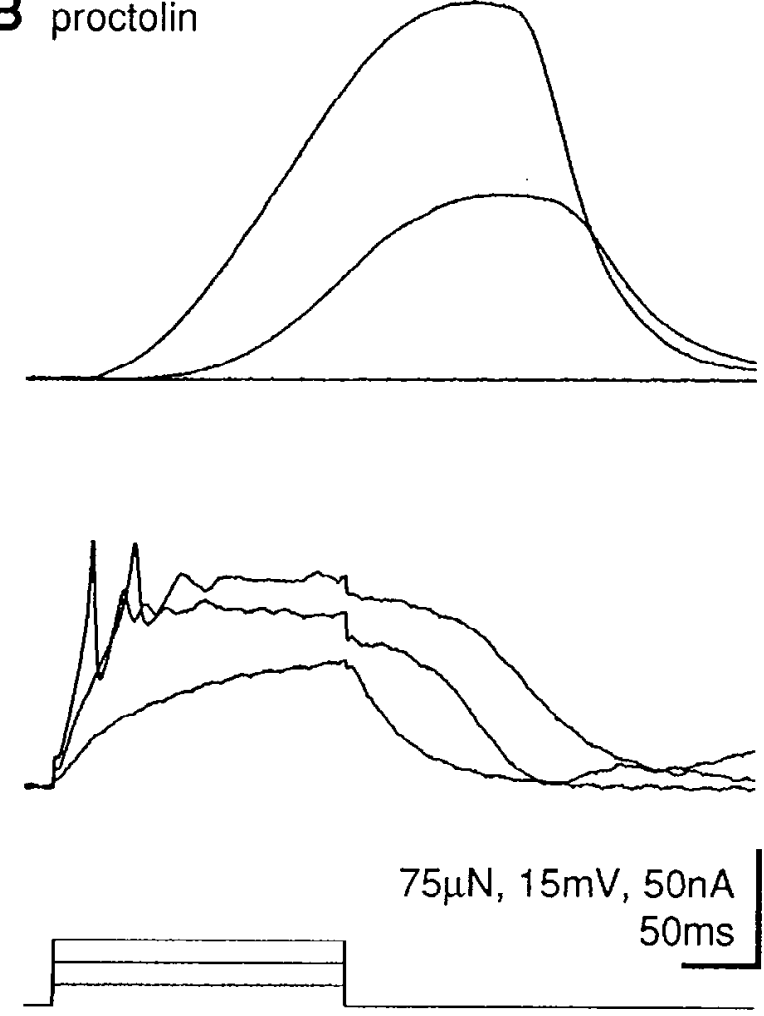
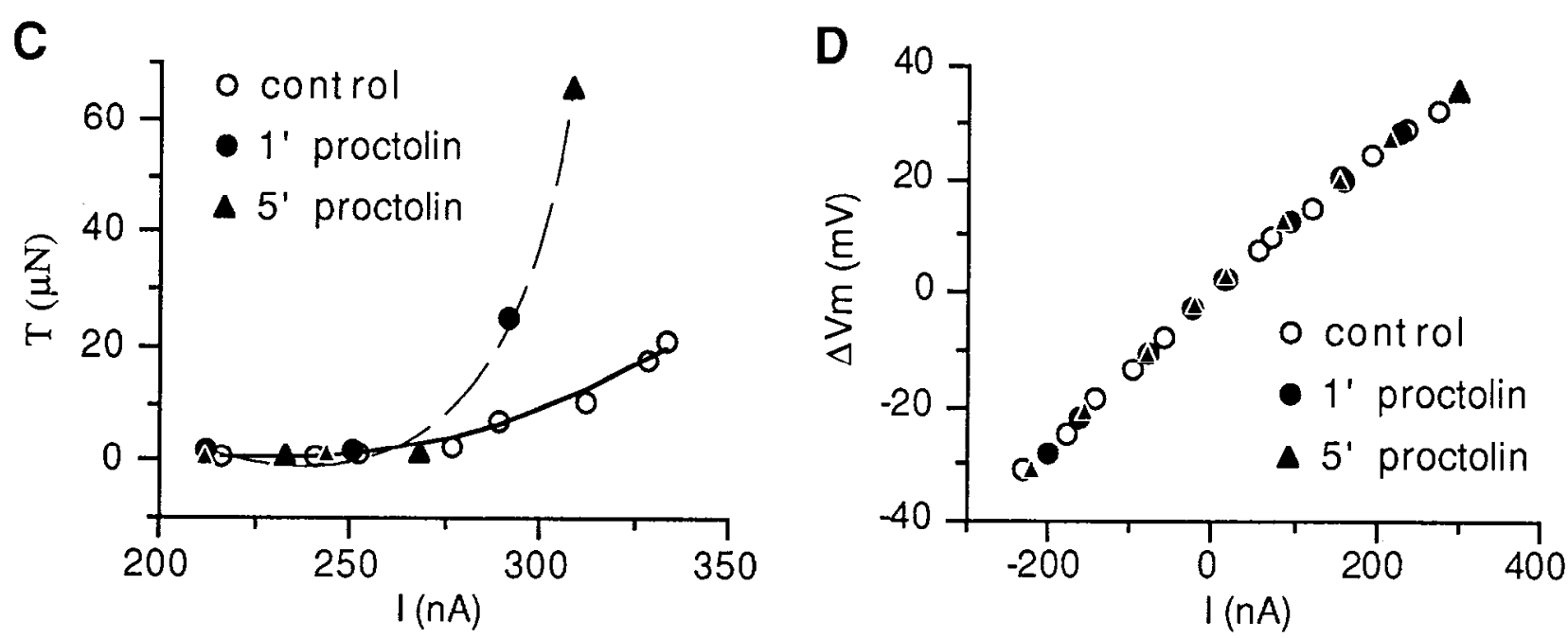

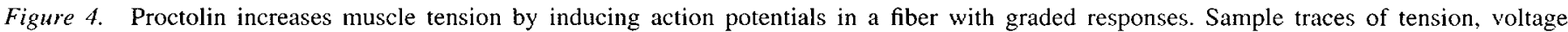

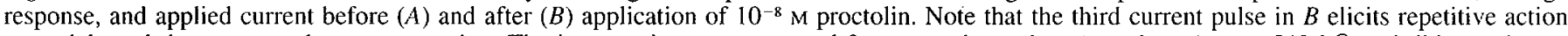

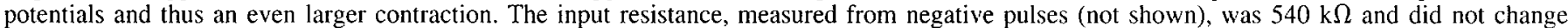

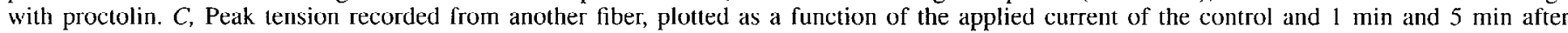

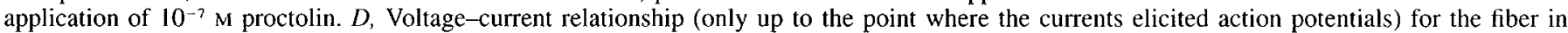
$C$ before and after proctolin. The membrane resting potential was $-69 \mathrm{mV}$ for both experiments.

the need to depolarize the patch, which would also activate any voltage-dependent channels present.

In the cell-attached configuration, the most frequently observed unitary currents at the cell's resting potential were from channels which showed no significant voltage dependence of their open probability. With hypotonic ASW in the patch pipette, currents appear to represent just a single $52 \pm 6 \mathrm{pS}(n=15)$ conductance and hence a single type of voltage-independent channel. An example of outward $\mathrm{K}^{+}$currents from a patch with several of these $50 \mathrm{pS}$ channels shows the fluctuations in singlechannel currents and the current-voltage relationship for the channels (Fig. 5). With high $\mathrm{K}^{+}$solution-that is, quasisymmetrical $\mathrm{K}^{+}$distribution-single-channel conductances ranged from 36 to $166 \mathrm{pS}$. Figure 6 shows current-voltage relationships 
A
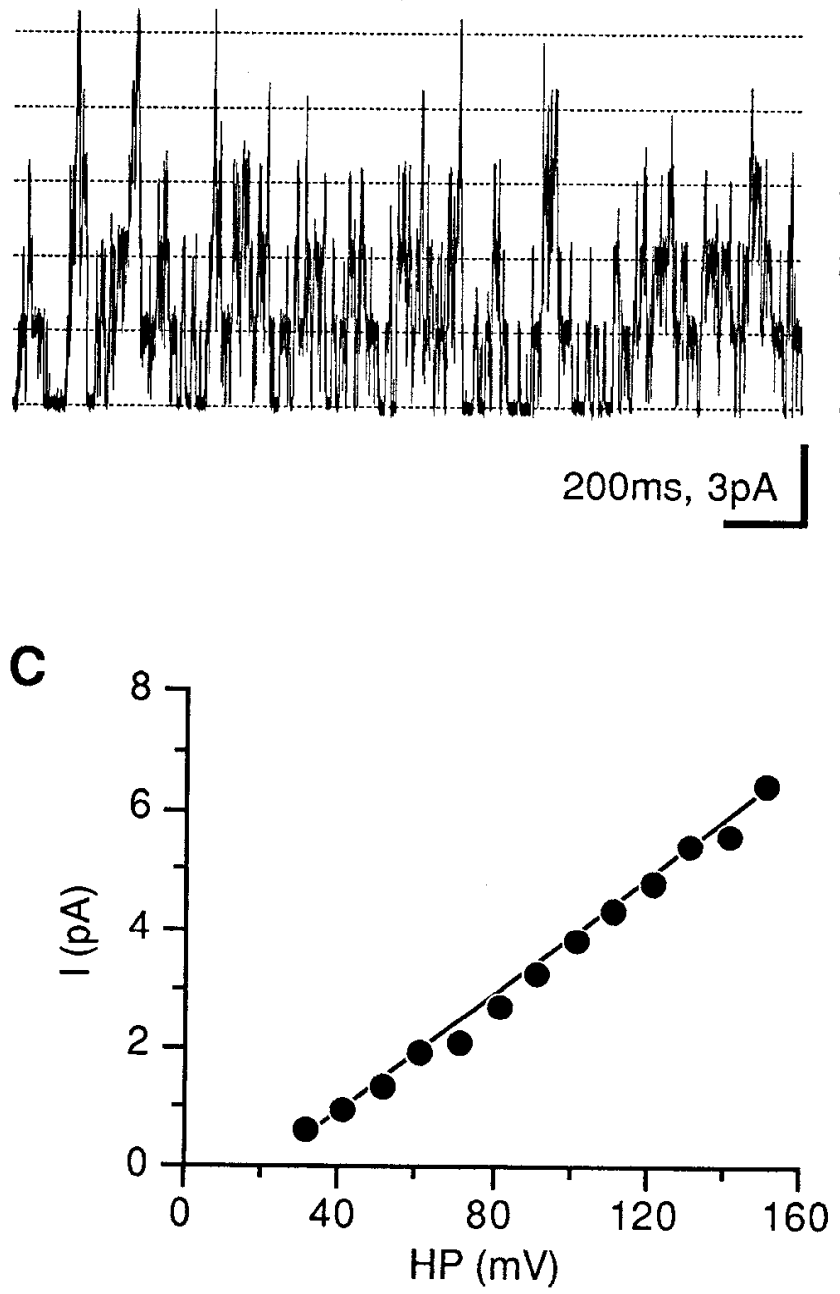

B

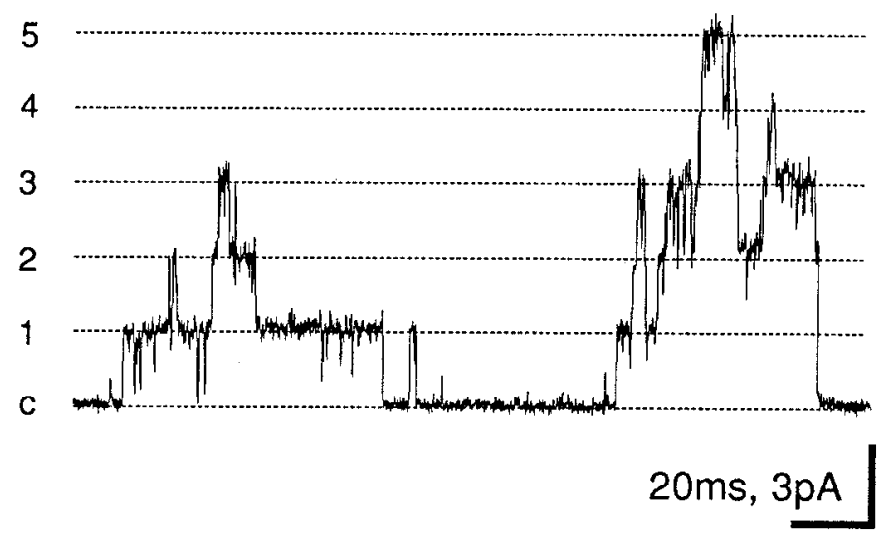

D

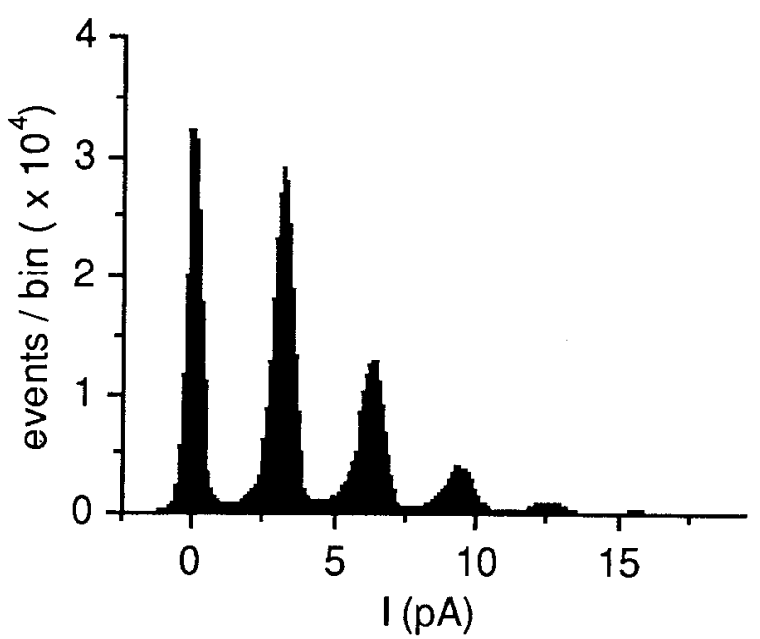

Figure 5. Unitary outward $\mathrm{K}^{+}$currents recorded from $48 \mathrm{pS}$ channels with ASW in the pipette. Single-channel records at $+80 \mathrm{mV}$ from the fiber's membrane resting potential are shown at different time resolutions to demonstrate fluctuations in single-channel current $(A)$ and channel gating $(B)$. The closed level of the channels are marked by $c$ and open levels by $I-5$. C, Unitary current through the channels as a function of patch potential (relative to the membrane resting potential). The regression line has a slope of $48 \mathrm{pS}$. $D$, Amplitude histogram of all data points during a $20 \mathrm{sec}$ record. The peaks represent the closed channel (at 0 current), one open channel (at $3.5 \mathrm{nA}$ ), and multiple openings of $2-5$ channels. All records were low-pass filtered at $3 \mathrm{kHz}$.

for these channels and the distribution of single-channel conductances obtained with both $\mathrm{ASW}$ and high $\mathrm{K}^{+}$solution in the patch pipette. The amplitude distribution of single-channel conductances for high $\mathrm{K}^{+}$solution shows three conductance classes as evident from the peaks at 45,95 , and $145 \mathrm{pS}$. To determine if the different conductances obtained with high $\mathrm{K}^{+}$solution were from one or several types of channels, we analyzed some of their gating behavior, the voltage dependence of their open probabilities, and the channels' reversal potentials. Representative single-channel currents for each conductance class are shown in Figure 7. All channels displayed the same characteristic burst behavior. The apparent closed times of multichannel patches (and all of our patches contained several channels) de pend critically on the number of channels in the patch. Therefore, measurement of the closed times was inappropriate in looking for channel differences or similarities. Even in multichannel patches, however, the closed times within distinct bursts of openings (Fig. 7) can reasonably be assumed to reflect the kinetics of one particular channel (Colquhoun and Sigworth, 1983).
Thus, we looked for isolated bursts of openings from the closed state of the channel to the first open level. We found that the open times within bursts were comparable for the three conductance classes since all open time distributions could be fitted by single exponentials with similar time constants (Fig. 7A-C). Openings of the $50 \mathrm{pS}$ channels obtained with ASW in the patch pipette, by comparison, also showed characteristic bursts (Fig. $7 D$ ), but the mean open time within a burst was much longer. This is not surprising, since the holding potentials for both conditions had to be very different. With high $\mathrm{K}^{+}$solution channels were recorded at the cells' resting potential, and with ASW depolarization $\geq 80 \mathrm{mV}$ from rest was necessary for single-channel currents with a signal-to-noise ratio adequate for kinetic analysis.

In addition, all channels (with ASW or high $\mathrm{K}^{+}$solution) were non-voltage dependent as determined from steady state open probability versus membrane potential relationships (Fig. 8). In terms of voltage change necessary for an e-fold change in $\mathrm{P}_{\mathrm{o}}$, only three of 13 channels for which a quantitative analysis was 

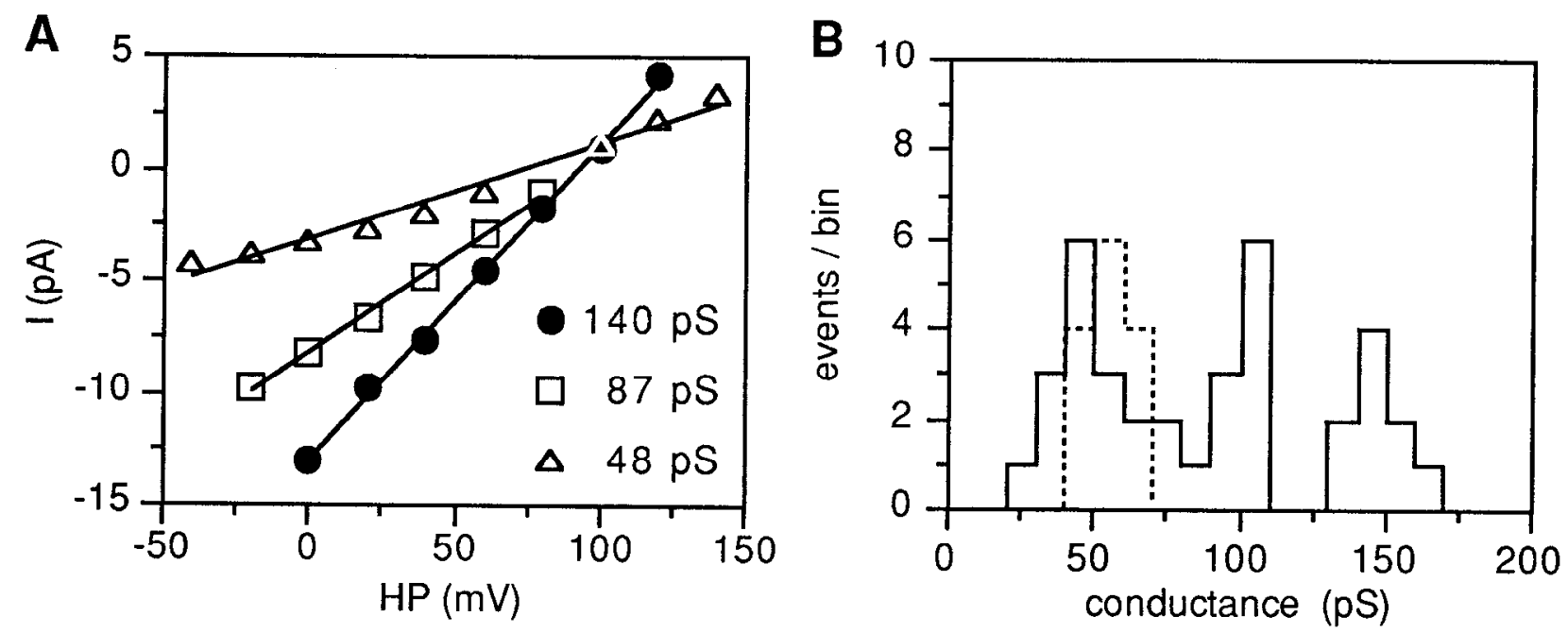

Figure 6. Single-channel current-voltage relationships and distribution of single-channel conductances of $\mathrm{K}^{+}$-permeable channels in cell-attached patches. A, Single-channel I-V curves from three representative channels obtained with high $\mathrm{K}^{+}$saline in the pipette. The lines are least squares fits of the data to a straight line with slopes of $140 \mathrm{pS}$ and a reversal potential $\left(\mathrm{V}_{\text {rev }}\right)$ of $+92 \mathrm{mV}(\mathbf{C}), 87 \mathrm{pS}$ and $\mathrm{V}_{\text {rev }}$ of $+94 \mathrm{mV}(\square)$, and $48 \mathrm{pS}$ and $\mathrm{V}_{\mathrm{rev}}$ of $+76 \mathrm{mV}(\triangle)$. Potentials are relative to the cell's resting membrane potential. $B$, Amplitude histogram of single-channel conductances determined from $\mathrm{I}-\mathrm{V}$ relationships as shown in $A$ from patches with high $\mathrm{K}^{+}$saline (solid line) and from patches with ASW (see Fig. $5 C$ ) in the recording pipette (dotted line).

carried out showed any significant voltage dependence with +73 , +63 , and $+45 \mathrm{mV}$ for an e-fold change in $P_{0}$. For the remaining channels the slopes were more than $\pm 100 \mathrm{mV}$ for an e-fold change in $\mathrm{P}_{0}$, as shown for the $148 \mathrm{pS}$ channel in Figure 8.

The channels were identified as putative $\mathrm{K}^{+}$channels on the basis of the current reversal potential which, in cell-attached patches with high $\mathrm{K}^{+}$solution in the pipette, was $+85 \pm 12$ $\mathrm{mV}$ ( $n=12$ ) depolarized from the resting potential. Assuming a resting potential of $-70 \mathrm{mV}$, the average value determined in the current-clamp experiments (see above), this is equivalent to an absolute value of $+15 \mathrm{mV}$. Upon excision into ASW (insideout configuration), the reversal potential shifted to positive potentials: current through a proctolin-sensitive $51 \mathrm{pS}$ channel, for example (see below), for which the I-V relationship was determined with voltage ramps (see Materials and Methods) from -100 to $+100 \mathrm{mV}$ (Fig. 9), reversed at $+78 \mathrm{mV}$ in the cellattached configuration. Again, assuming a resting potential of $-70 \mathrm{mV}$, this corresponds to an absolute reversal potential of $+8 \mathrm{mV}$, as expected for the approximately symmetrical $\mathrm{K}^{+}$distribution on both sides of the patch. After excision into ASW, only inward currents werc detcetcd, consistent with the new $\mathrm{K}^{+}$ distribution. Finally, again in the inside-out configuration, when ASW was replaced by high $\mathrm{K}^{+}$solution, single-channel currents reversed close to $0 \mathrm{mV}(+6 \mathrm{mV})$; again, as expected for $\mathrm{K}^{+}$ channels in symmetrical $\mathrm{K}^{+}$solution.

For cell-attached patches with hypotonic ASW in the recording pipette, unitary inward and outward currents near the fiber's resting potential were too small to be resolved, but outward currents increased with depolarization (Fig. 5C). Again, this is consistent with the channels being $\mathrm{K}^{+}$selective.

Since channels of all conductances were largely voltage insensitive, with similar reversal potentials and similar gating, we refer to them as a single class of channels. It is not clear if the different conductances observed with high $\mathrm{K}^{+}$solution in the pipette actually are from distinct channels or if they represent one channel displaying several conductance states (see Discussion). With both recording solutions, channels were clustered: patches $\left(\approx 5 \mu \mathrm{m}^{2}\right)$ showed either very low to no activity, or contained several (usually 4-10) channels. Patches with a high density of channels were found to be homogeneous; that is, single-channel currents were multiples of the smallest current (Fig. 5, and see Figs. 10, 13).

\section{Proctolin closes a class of voltage-independent $K^{+}$-permeable channels}

Even on a time scale of seconds, channel activity fluctuated considerably (Fig. 5A, and see Figs. 10,13). Consequently, only patches that were stable over tens of minutes and had several active channels could be used to examine the effects of proctolin. In these multichannel patches, activity of the non-voltagedependent $\mathrm{K}^{+}$-permeable channels was found to be modulated by proctolin. Upon bath application of proctolin in the range of $5 \times 10^{-9} \mathrm{M}$ and $5 \times 10^{-7} \mathrm{M}$ (final concentration), channel activity decreased within 1 min. A particularly good example of modulation of single-channel activity by proctolin is shown in Figure 10 . This patch, obtained with high $\mathrm{K}^{+}$solution in the recording pipette, had $\geq 10$ active $166 \mathrm{pS}$ channels. Application of $5 \times 10^{-7} \mathrm{M}$ proctolin decreased channel activity by $91 \%$. Activity returned to $48 \%$ of the control level within $5 \mathrm{~min}$ of perfusion of the bath with ASW, and channel activity was again reduced by $92 \%$ during a second application of the peptide. Similar reduction of channel activity by proctolin was investigated in three other patches with high $\mathrm{K}^{+}$solution in the recording pipette $(50,51,137 \mathrm{pS}$ channels), and in two with hypotonic ASW $(50 \mathrm{pS})$ in the recording pipette. On the average, proctolin reduced $\mathrm{K}$-permeable channel activity by $63 \pm 23 \%$ (eight applications, six preparations).

The reduction of single-channel activity by proctolin was not accompanied by a change in the single-channel current amplitudes (Fig. 10), which indicates that the peptide acts by reducing the number of active channels in the patch rather than by affecting single-channel conductance. (A change in single-channel current amplitudes due to a change in membrane potential is not expected, since macroscopic measurements under current-clamp conditions showed no change in membrane resting potential upon application of proctolin.) To test for possible effects of 
A
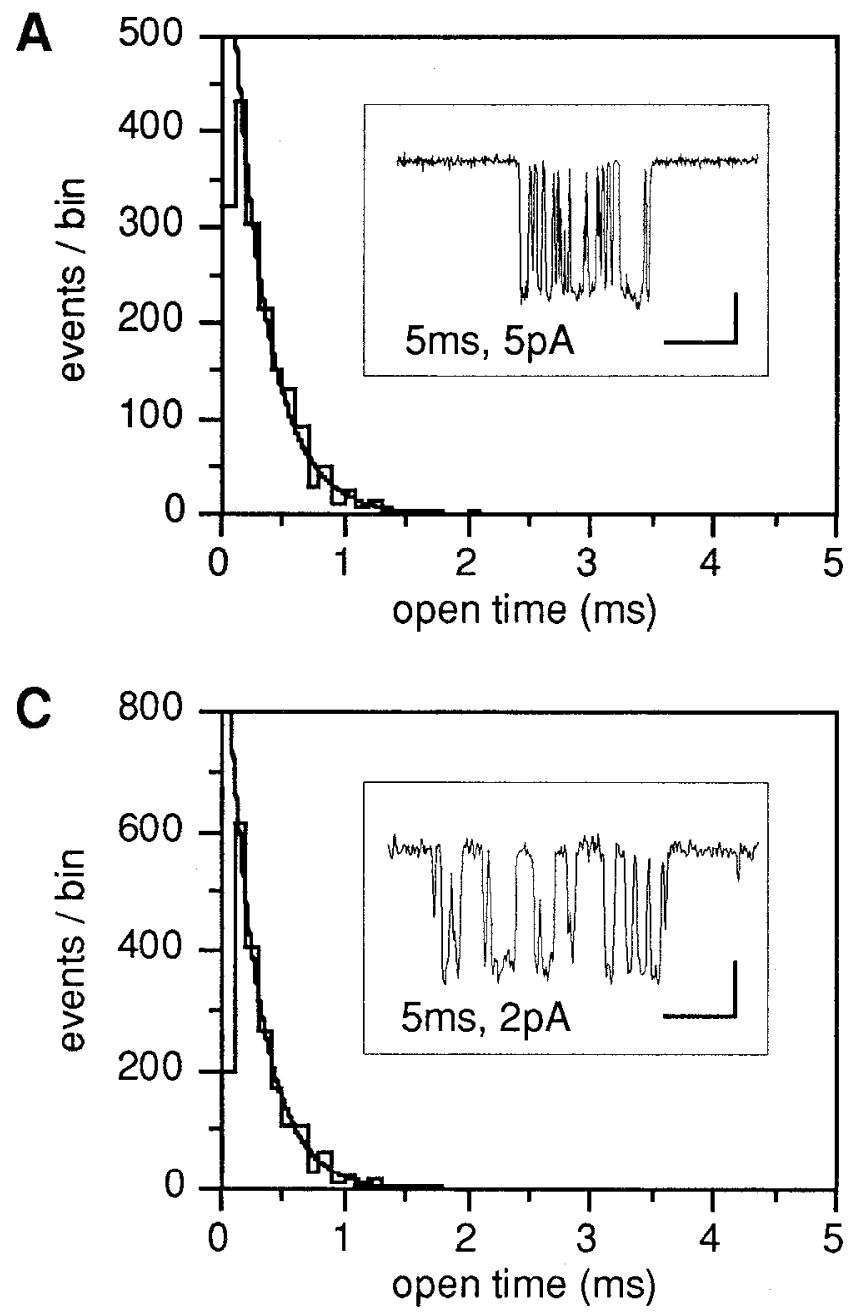
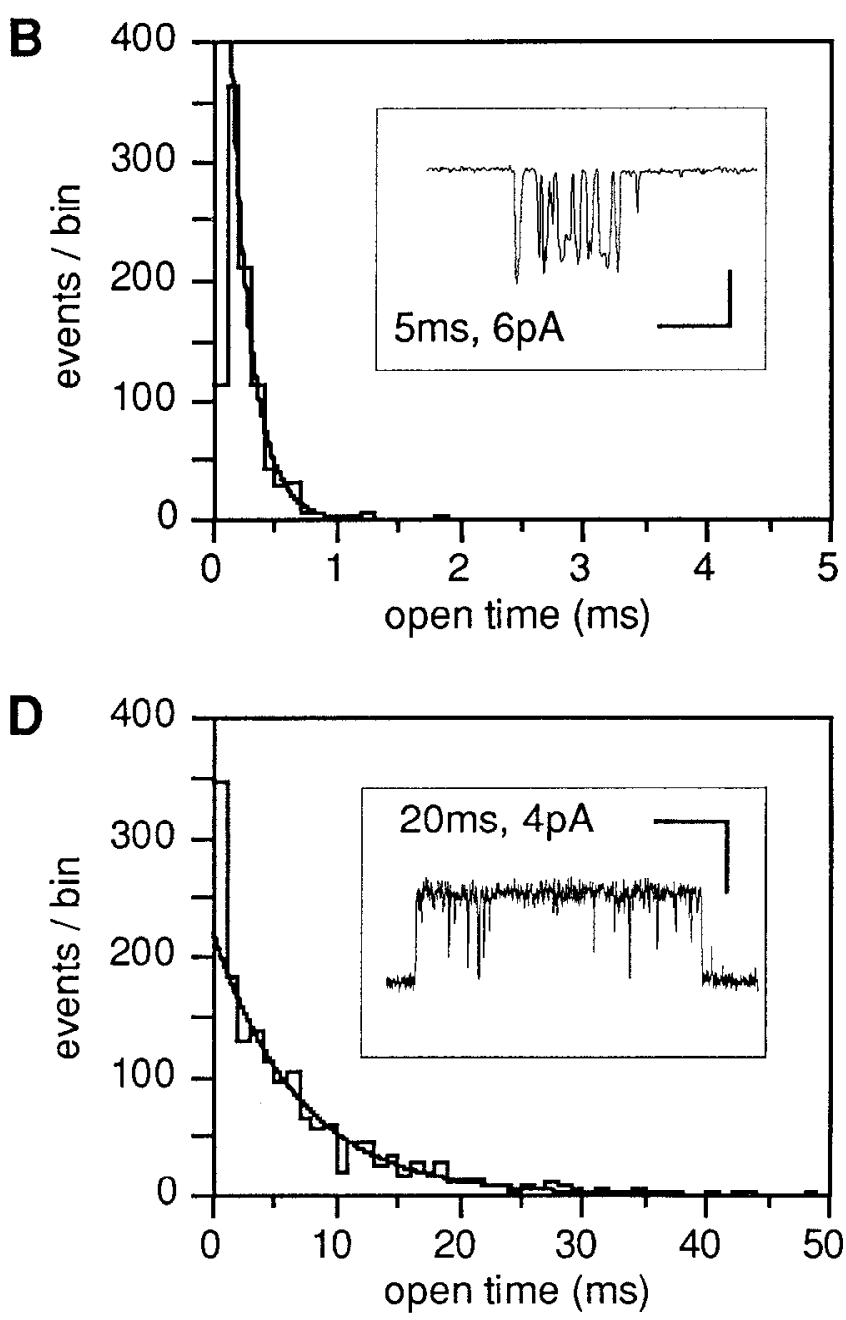

Figure 7. Non-voltage-dependent $\mathrm{K}^{+}$-permeable channels with different conductances have similar gating properties. Open time distributions determined from inward currents through single channels during bursts of openings (insets) of a 137 pS channel with a mean open time of 0.3 msec $(A)$, a $96 \mathrm{pS}$ channel with a mean open time of $0.2 \mathrm{msec}(B)$, and a $36 \mathrm{pS}$ channel with a mean open time of $0.3 \mathrm{msec}(C)$. $D$, Open time distribution from unitary outward currents during burst of openings (inset) of a $48 \mathrm{pS}$ channel with a mean open time of $5.9 \mathrm{msec}$. Data and records for the figures were low-pass filtered at $8 \mathrm{kHz}(A)$ and $3 \mathrm{kHz}(B, C, D)$. The smooth curves are single exponential fits with the indicated time constants. Cell-attached patches with high $\mathrm{K}^{+}$solution in the pipette held at the fiber's resting membrane potential $(A-C)$ and with ASW in the pipette held at $+120 \mathrm{mV}$ from the fiber's resting potential $(D)$.

proctolin on single-channel kinetics, open and shut times for isolated bursts from the closed to the first open level, similar to the analyses for the conductances classes (Fig. 7), were measured. For the patch shown in Figure 10, for example, open and closed times that were determined from dwell-time distributions during the control periods and after proctolin applications show very little and inconsistent differences in the parameters (Fig. 11). The differences are in any case insufficient to explain the drastic reduction in single-channel activity with proctolin.

\section{Effects of proctolin are mimicked by elevation of intracellular} CAMP and reversed by an inhibilor of the protein kinase $A$

Since involvement of the cAMP signal pathway was implied for proctolin effects in other preparations (Evans, 1984; Swales and Evans, 1988; Bishop et al., 1991a), we tested the ability of exogenous cAMP to imitate the effects of proctolin. We used the membrane-permeable cAMP analog dibutyryladenosine 3', 5'cyclic monophosphate (db-cAMP, $10^{-4} \mathrm{M}$ ), along with an inhibitor of the cAMP phosphodiesterase, 3-isobutyl-1-methyl-xanthine (IBMX, $10^{-4} \mathrm{M}$ ). Within $5-15 \mathrm{~min}$ of application (Fig.
$12 A)$, there was an increase in input resistance of the muscle fibers $(+25 \pm 8 \%, n=3$, see Fig. 14), much like the effect observed with proctolin. Elevation of intracellular cAMP also increased the contraction amplitude (two- and threefold, $n=2$ ).

The effect of $\mathrm{db}-\mathrm{cAMP} / \mathrm{IBMX}$ on the activity of non-voltagedependent $\mathrm{K}^{+}$-permeable channels was indistinguishable from that of proctolin. In the example shown in Figure 13, there was an $89 \%$ reduction of single-channel activity after application of $10^{-4} \mathrm{M} \mathrm{db}-\mathrm{cAMP}$ and $10^{-4} \mathrm{M}$ IBMX. In two other experiments, also with hypotonic $A S W$ in the recording pipette, $\mathrm{db}$-cAMP plus IBMX reduced the open probability of the $50 \mathrm{pS} \mathrm{K} \mathrm{K}^{+}$-permeable channels by $89 \%$ and $60 \%$. As shown for the action of proctolin, elevation of internal cAMP seems to reduce the number of active channels, rather than change any of the other sin gle-channel parameters. In the example shown in Figure 13, the mean open time (at $+80 \mathrm{mV}$ depolarization) derived from dwelltime distributions was $5.9 \mathrm{msec}$ under control conditions and 6.2 msec after application of db-cAMP/IBMX.

The diastereomer of cyclic adenosine 3', 5'-monophosphothioate (Rp-cAMPS) is known to bind to but not activate the 
A

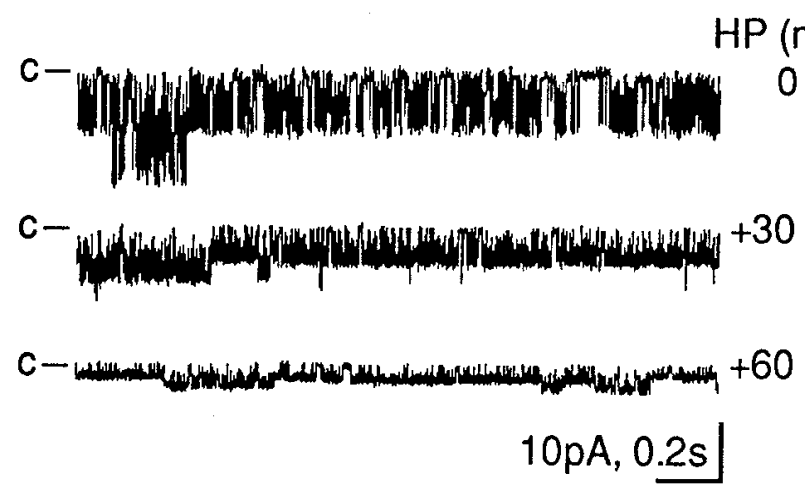

B

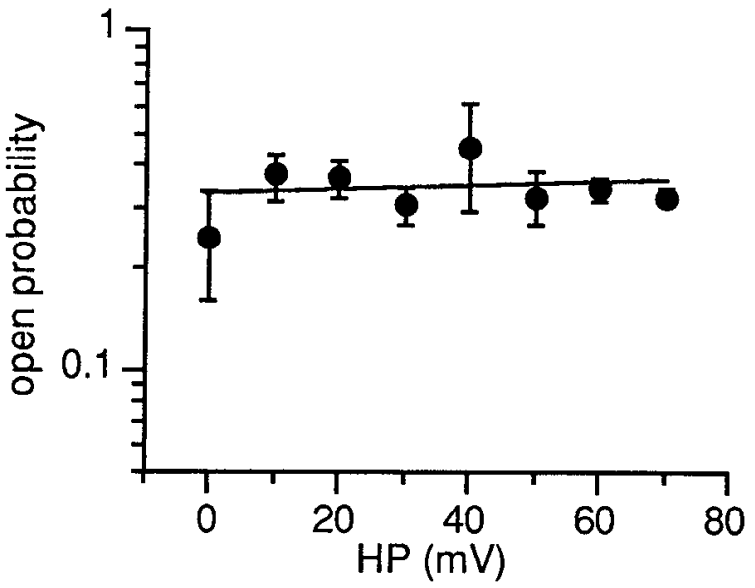

Figure 8. Steady state open probability $\left(\mathrm{P}_{\mathrm{s}}\right)$ of a $148 \mathrm{pS} \mathrm{K} \mathrm{K}^{+}$-permeable channel is independent of the membrane potential. $A$, Single-channel records at potentials shown with each trace; $c$ marks the closed level for the channels; records low-pass filtered at $1 \mathrm{kHz}$. $B$, $\mathrm{P}_{0}$ determined from four $3 \mathrm{sec}$ segments (like those shown in $A$ ) at each potential. The line is a least squares fit of the data to a straight line and the "slope" corresponds to a voltage sensitivity of $+460 \mathrm{mV}$ for an e-fold change in $\mathrm{P}_{0}$; error bars are standard deviations. Potentials are relative to the cell's resting membrane potential; cell-attached patch with three active channels; high $\mathrm{K}^{+}$solution in the pipette.

cAMP-dependent protein kinase, thereby effectively inhibiting the enzyme (De Wit et al., 1984). Rp-cAMPS had the opposite effect of either cAMP or proctolin. It reduced the membrane input resistance on the average by $28 \pm 8 \%(n=5$, Fig. 14). At the concentration used $\left(2 \times 10^{-5} \mathrm{M}\right)$, it took $20-40 \mathrm{~min}$ for the Rp-cAMPS effects to fully develop. In three preparations that were stable enough to allow recordings over several hours, Rp-cAMPS effects were reversed after washout of 40-65 min. The clearest example of a reversible Rp-cAMPS effect on the $\mathrm{V}-\mathrm{I}$ relationship is shown in Figure $12 \mathrm{~B}$. In this experiment, the input resistance decreased by $50 \%$ and returned to the control value after 40 min of washout with ASW. We conclude from the cyclic nucleotide expcriments that the cAMP pathway and, most likely, protein kinase $A$ are involved in the proctolin-induced potentiation of contractions in the muscle fibers of Idotea.

\section{Discussion}

The main finding of our simultaneous current-clamp and contraction measurements on single, isolated fast muscle fibers of

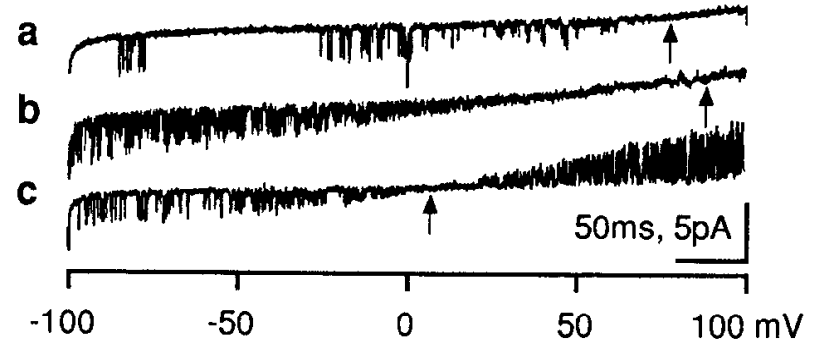

Figure 9. $\mathrm{K}^{+}$selectivity of a proctolin-sensitive $51 \mathrm{pS}$ channel demonstrated by voltage ramps. Single-channel currents during voltage ramps from -100 to $+100 \mathrm{mV}(0.5 \mathrm{sec}$ duration $)$ in $a$, a cell-attached patch with high $\mathrm{K}^{+}$saline in the pipette. $b$, Currents after excision (inside-out configuration) into ASW. $c$, After exchange of the bath solution for high $\mathrm{K}^{+}$saline. Reversal potentials, marked by arrows, were determined from steady state I-V curves (cf. Fig. 7), and were +78 $\mathrm{mV}$ in $a, \sim+90 \mathrm{mV}$ in $b$, and $+6 \mathrm{mV}$ in $c$. The potentials for the excised patch configurations $(b, c)$ are absolute trans-patch potentials (inside relative to outside), whereas the potentials for the ccll-attached configuration $(a)$ are relative to the cell's resting membrane potential. the isopod Idotea is that proctolin increases the contraction amplitudes by increasing the membrane resistance $\mathrm{R}_{\mathrm{i}}$ through closure of $\mathrm{K}^{+}$-permeable ion channels. While the change in $\mathrm{R}_{\mathrm{i}}$ is not the only effect of proctolin (see below), it seems sufficient to explain the increase in contraction amplitudes due to an increase in the voltage response in those experiments where the only effect of proctolin was an increase in input resistance (without the induction of action potentials, Fig. 2). This becomes obvious when the contraction amplitudes are plotted as a function of depolarization rather than of the applied current (Fig. $2 C, D$ ). Since the data of the controls and after proctolin application fall on the same "line," neither a shift in the excitationcontraction (E-C) threshold nor effects on subsequent steps of E-C coupling seem necessary to explain the increase in peak tension with proctolin. An increase in the effectiveness of E-C coupling on the basis of depolarization versus peak tension relationship is, for example, thought responsible for the large postsynaptic effects of serotonin in the leg opener muscle of the crayfish (Fischer and Florey, 1983).

We have identified a class of voltage-independent $\mathrm{K}^{+}$-permeable channels in cell-attached patches as those contributing to the resting conductance of the muscle fibers. Since most single-channel currents were recorded cell attached, and the experiments were primarily designed to study modulation of the channels by proctolin, their biophysical characterization is still incomplete. In particular, our results show that the channels are $\mathrm{K}^{+}$permeable but a strict $\mathrm{K}^{+}$selectivity can be shown only in excised patches, as demonstrated for one proctolin-sensitive channel (Fig. 9). However, the important point with respect to the action of proctolin is that the channels are active at the membrane resting potential, and thus contribute to the resting conductance. As shown here, the "background" channels are modulated by proctolin, which reduces the number of active channels with no significant effect on either single-channel conductance or channel open and closed times within bursts. The biological significance of the resulting increase in membrane resistance is an increase in the amplitude of synaptic junction potentials and their summation properties and thus a decrease in the threshold 

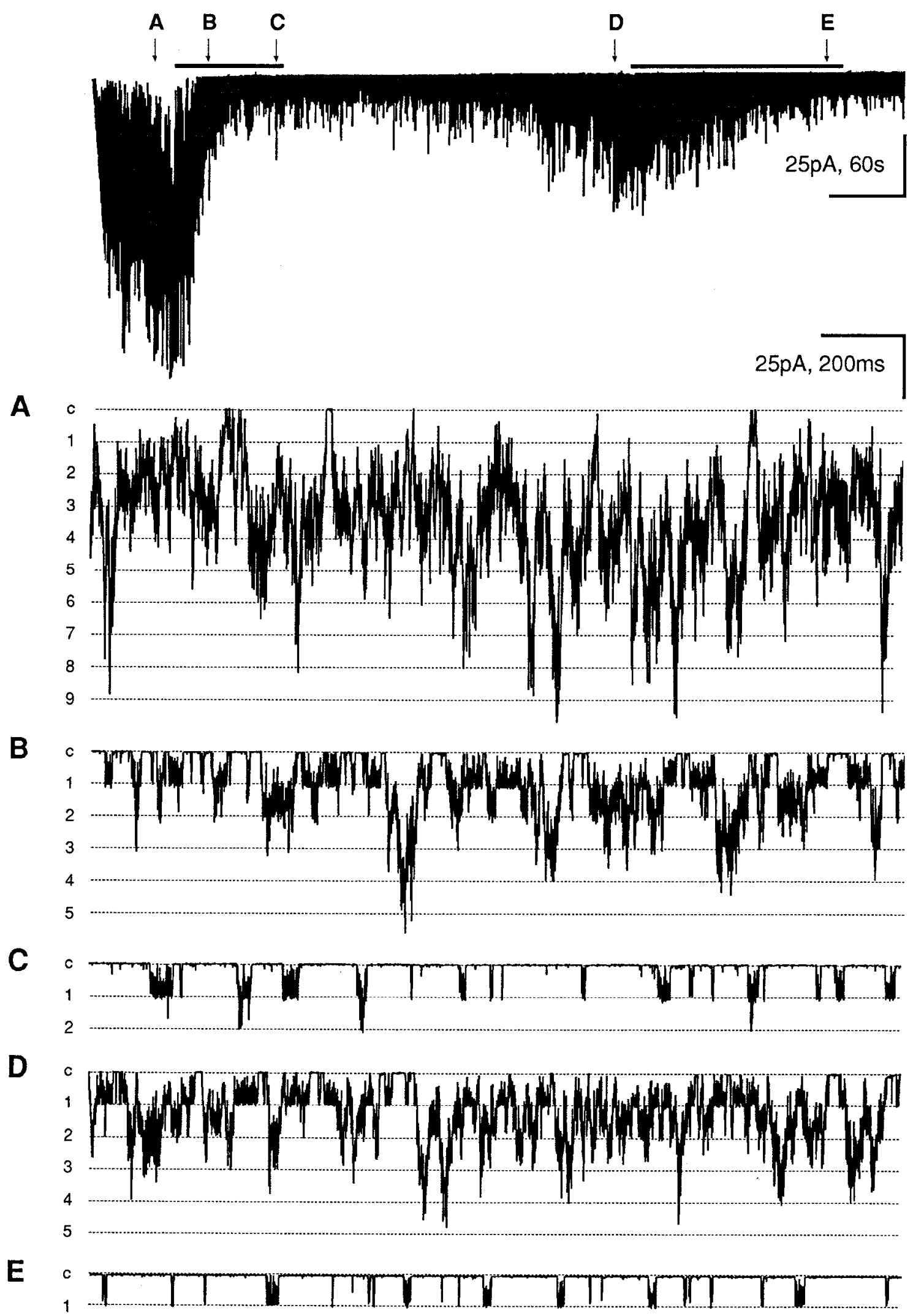

Figure 10. Proctolin reversibly reduces the activity of non-voltage-dependent $166 \mathrm{pS} \mathrm{K} \mathrm{K}^{+}$-permeable channels. The top trace shows 10 min of recordings from a cell-attached patch with $\geq 10$ active channels. $A-E$, Sample traces at higher time resolution at times indicated above the top trace show inward $\mathrm{K}^{+}$currents before application of $10^{-7} \mathrm{M}$ proctolin $(A)$, and in the presence of the peptide $(B$, $C$; horizontal bar). After the first application, the bath was perfused with ASW until the second proctolin application (second horizontal bar). D, Partial recovery of activity. E, Activity during a second application of $10^{-7} \mathrm{M}$ proctolin after which the patch was lost during a second wash with ASW. Recording with high $\mathrm{K}^{+}$ solution in the pipette at the fiber's membrane resting potential. Top trace low-pass filtered at $30 \mathrm{~Hz}$, and traces $A-E$ at $1 \mathrm{kHz}$. Dotted lines and numbers along the traces in $A-D$ indicate individual conductance levels, and the closed level of the channels are marked by $c$. 


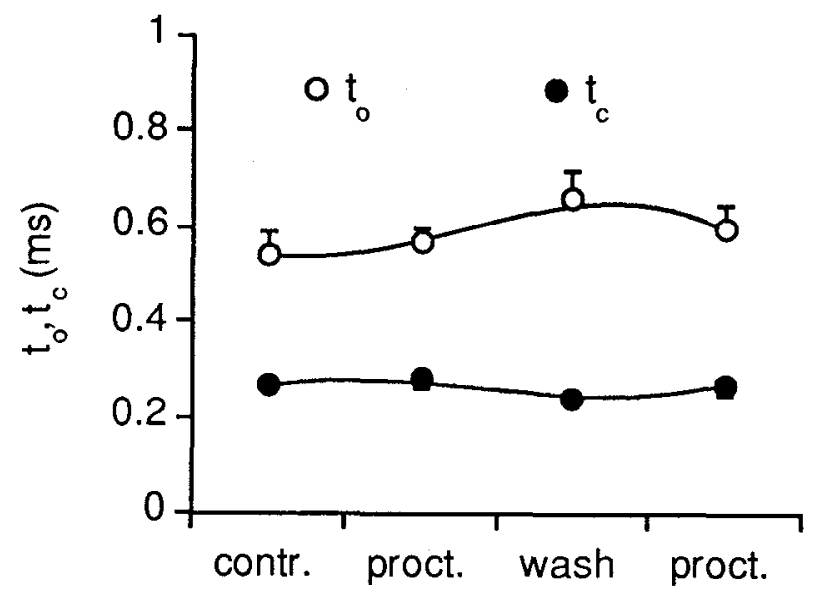

Figure 11. Proctolin has little effect on the burst kinetics of the nonvoltage dependent $\mathrm{K}^{+}$permeable channels. Open and shut times of bursts of openings from the closed to the first open level from a cellattached patch (same as Fig. 10) during a control period, after a first application of $10^{-7} \mathrm{M}$ proctolin, after washout, and after a second proctolin application. Error bars represent the error of single exponential fits of dwell-time histograms from which the data points were obtained.

for neurally evoked contractions of the muscle fibers. Even though the increase in input resistance is fairly modest (maximally $25 \%$ ), the increase in force of contraction is substantial, due to the highly nonlinear relationship between membrane depolarization and tension (Fig. 2D). This seems to be one of probably several mechanisms by which proctolin modulates the efficiency of motor patterns controlling muscle performance. Preliminary immunocytochemical results indeed show proctolinlike immunoreactivity in the CNS and on the abdominal extensor muscle fibers of Idotea baltica (Erxleben, Kreissl, and Rathmayer, unpublished observations).

Probably the most well-characterized $\mathrm{K}^{+}$channel with comparable function is the " $\mathrm{S}$ " channel $\left(\mathrm{K}_{\mathrm{S}}\right)$ of Aplysia neurons. Activity of $\mathrm{K}_{\mathrm{S}}$ channels is downregulated by serotonin via phosphorylation by protein kinase A (Siegelbaum et al., 1982), and upregulated by the peptide FMRFamide (Belardetti et al., 1987; Brezina et al., 1987) via lipoxygenase metabolites (Piomelli et al., 1987). Modulation by phosphorylation/dephosphorylation of the non-voltage-dependent $\mathrm{K}^{+}$-permeable channels presented here remains to be shown in excised patches and would strengthen the argument that "background" $\mathrm{K}^{+}$channels are important for the regulation of excitability not only in nerve cells but also in muscle fibcrs.

With few exceptions, studies on ion channels in arthropod muscle deal with voltage-dependent $\mathrm{K}^{+}$channels rather than non-voltage-dependent channels. In cultured locust muscle, a 207 pS K $\mathrm{K}^{+}$channel with little voltage dependency has been described (Miller and Usherwood, 1990). A large number of $\mathrm{K}^{+}$ channels with conductances ranging from 32 to $380 \mathrm{pS}$, some with little voltage dependence, were recently described in excised sarcolemmal membrane blebs from lobster skeletal muscle (Worden et al., 1993). It is not clear why we observed a single class of voltage-independent $\mathrm{K}^{+}$-permeable channels with a slope conductance of $52 \mathrm{pS}$ with ASW in the recording pipette, but several conductances ranging from 36 to $166 \mathrm{pS}$ with high $\mathrm{K}^{+}$solution in the pipette. Under both recording conditions, however, $\mathrm{K}^{+}$-permeable channel kinetics are similar; that is, channel openings occur in characteristic bursts and the channels are downregulated by proctolin. It is conceivable that high external $\mathrm{K}^{+}$not only shifts the voltage range of activation of $\mathrm{K}^{+}$ channels as shown, for example, for lymphocytes (Cahalan et al., 1985) or heart muscle (Kurachi, 1985), but also increases the probability of occurrence of subconductance states or formation of channel oligomeres. Interestingly, the large number of $\mathrm{K}^{+}$channels in lobster skeletal muscle (Worden et al., 1993) was also observed with high $\mathrm{K}^{+}$solution in the recording pipette.

There is an apparent discrepancy between the average reduction of single $\mathrm{K}^{+}$-permeable channel activity by proctolin $(-63$ $\pm 23 \%$ ) and the increase in input resistance, which amounted to maximally $25 \%$. The single-channel experiments, however, do not necessarily allow extrapolation to the whole-cell current or input resistance, since high activity and/or a large number of these channels were observed in a small number of patches. While the non-voltage-dependent $\mathrm{K}^{+}$-permeable channels, if present, were effectively downregulated by proctolin, they might constitute only a fraction of the input resistance. Why is there no decrease in membrane resting potential as a result of the
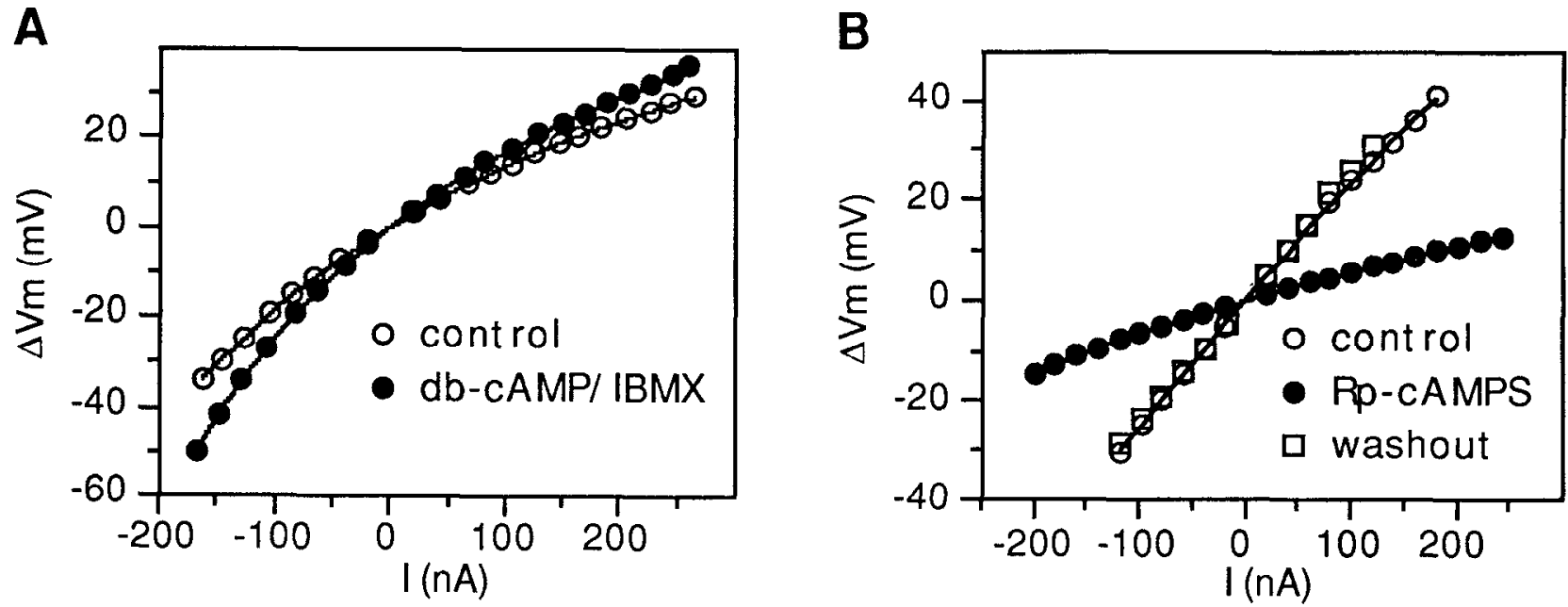

Figure 12. Effect of cAMP derivatives on the voltage-current relationship of the muscle fibers. $A$, Increase in membrane resistance by $10^{-4} \mathrm{M}$ $\mathrm{db}$-cAMP $+10^{-4}$ M IBMX. O, control; O 22 min after application of db-cAMP/IBMX. B, Decrease in membrane resistance by $2 \times 10^{-5} \mathrm{M}$ RpcAMPS. $\bigcirc$, control;, 40 min after application of Rp-cAMPS; $\square, 40$ min after washout. 

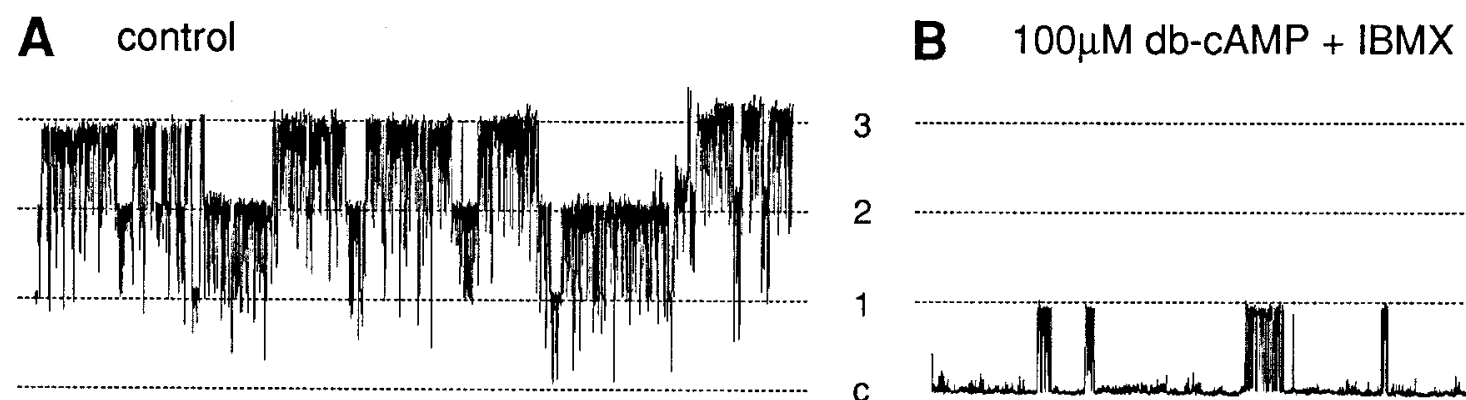

$2 \mathrm{~s}, 5 \mathrm{pA}$

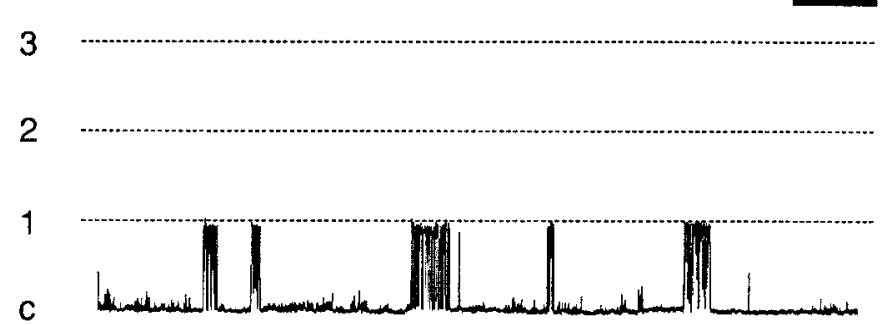

Figure 13. Decrease in single-channel activity of a non-voltage-dependent $50 \mathrm{pS} \mathrm{K} \mathrm{K}^{+}$-permeable channel after application of $10^{-4} \mathrm{M} \mathrm{db}-\mathrm{cAMP}$ and $10^{-4} \mathrm{M}$ IBMX. Sample traces of outward $\mathrm{K}^{+}$currents during $20 \mathrm{sec}$ of a control $(A)$ and $8 \mathrm{~min}$ after application of db-cAMP/IBMX $(B)$. The average reduction of single-channel activity by cAMP/IBMX was $89 \%$. Cell-attached patch with ASW in the recording pipette and the patch depolarized by $100 \mathrm{mV}$. Sample traces low-pass filtered at $300 \mathrm{~Hz}$. Dotted lines and numbers along the traces indicate individual conductance levels, and the closed level of the channels are marked by $c$.

closure of $\mathrm{K}^{+}$channels by proctolin? If $\mathrm{K}^{+}$channels, proctolin sensitive or not, are predominant at the resting potential, little if any effect on the resting potential can be expected, provided that the "leak" conductance due to the activity of either nonselective channels, or $\mathrm{Na}^{+}$or $\mathrm{Ca}^{2+}$ channels is low. A small resting "leak" conductance is in fact consistent with our single-channel recordings, where we rarely found activity of other than $\mathrm{K}^{+}$channels at the resting potential.

Rp-cAMPS decreased the input resistance to substantially below control values. This effect not only substantiates the role of cAMP in the proctolin response but also offers a possible explanation for the variability that we found in the proctolin responsc. We interpret the decrease in input resistance as the opening of previously silent non-voltage-dependent $\mathrm{K}^{+}$channels. It can be caused by block of a protein kinase $\mathrm{A}$ by the thio-cAMP analog Rp-cAMPS, which prevents phosphorylation after either spontaneous or phosphatase-mediated dephosphorylation of the channels (or closely associated proteins). The pronounced effect of Rp-cAMPS on the macroscopic V-I curve (Fig. 12B) probably includes effects on ion channels (and possibly pumps or carriers) other than the non-voltage-dependent $\mathrm{K}^{+}$-permeable channels that are modulated by proctolin; but the reduction of

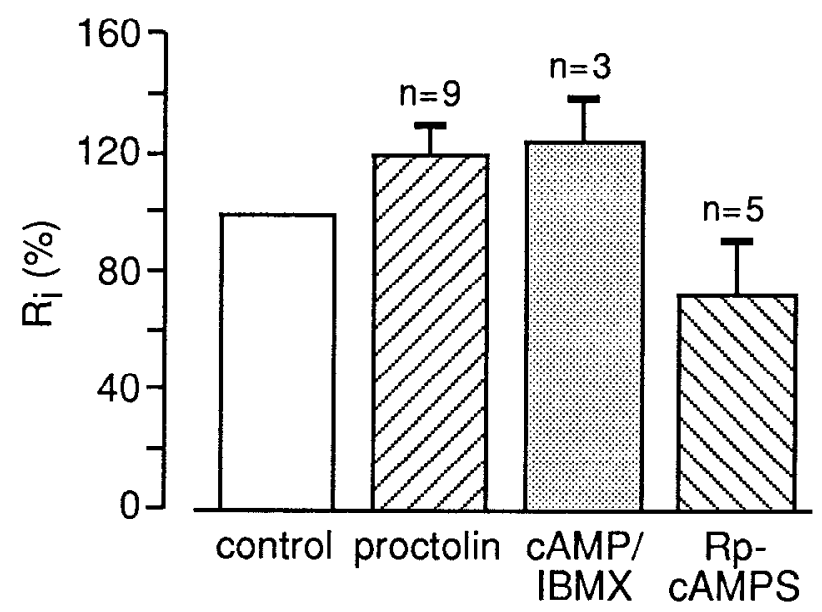

Figure 14. Summary of the effects of proctolin and cAMP derivatives on the input resistance of the muscle fibers. Each column represents the mean change in input resistance from the number of experiments indicated above it. Error bars denote standard deviations of the mean. Proctolin $2 \times 10^{-9}-10^{-8} \mathrm{M}, \mathrm{db}$-cAMP + IBMX $10^{-4} \mathrm{M}$, Rp-cAMPS $2 \times$ the input resistance to below control levels by Rp-cAMPS suggests a basal level of phosphorylation, which might differ between animals or even between fibers and, in addition, be subject to seasonal changes. Interestingly, during a series of experiments in which we found very little, if any, change in membrane resistance or force of contraction with proctolin or db-cAMP, the input resistance of the muscle fibers-among muscle fibers of comparable size-was significantly higher in the nonresponsive group ( $720 \pm 238 \mathrm{k} \Omega n=8$ ) than in a similar group of preparations that responded to the peptide $(303 \pm 94 \mathrm{k} \Omega n=10)$. High input resistance might thus simply indicate an already high level of intracellular cAMP and/or A-kinase activity, in which casc no morc channels can bc closcd via phosphorylation by proctolin or exogenous cAMP. Seasonal variability in $\mathrm{Ca}^{2+}$ channel modulation by proctolin has been observed by Bishop et al. (1991b) in slow flexor muscle fibers of the crayfish. Responsiveness could be restored by previous incubation with octopamine (Bishop et al., 1991b).

In addition, our results confirm those of earlier investigations concerning the possible action of proctolin on $\mathrm{Ca}^{21}$ channels. In one-fourth of our preparations, we observed that graded depolarizations in response to current stimulation were converted into all-or-nothing $\mathrm{Ca}^{2+}$ action potentials (Fig. $4 A, B$ ) after application of proctolin. Appearance of $\mathrm{Ca}^{2+}$ action potentials in response to proctolin but also to octopamine and serotonin was previously reported for lobster opener muscle (Kravitz et al., 1980). $\mathrm{Ca}^{2+}$ dependence of proctolin action was found in most preparations (reviewed in Orchard et al., 1989), and proctolin induces spikelike membrane oscillations in body wall muscles of Lucilia larvae (Irving and Miller, 1980) and in Limulus heart muscle (Watson et al., 1983). While these studies and our own suggest modulation of $\mathrm{Ca}^{2+}$ channels by proctolin, the most compelling and direct evidence for $\mathrm{Ca}^{2+}$ channel modulation is the demonstration by Bishop et al. (1991a) of proctolin-sensitive $\mathrm{Ca}^{2+}$ channels with patch-clamp recordings on abdominal tonic flexor muscle fibers of the crayfish.

A similar decrease in resting conductance by proctolin as shown here for abdominal extensor muscle fibers of Idotea baltica was observed in several other preparations. In locust skeletal muscle, voltage-clamp measurements of a $\mathrm{K}^{+}$leak conductance showed that the resting conductance decrease by proctolin and FMRFamide is mediated by a G-protein (Murck et al., 1989). In cardiac ganglia of the lobster, proctolin causes a 10-30\% increase in input resistance, also proposed to reflect a decrease 
in resting $\mathrm{K}^{+}$conductance (Miller and Sullivan, 1981; Sullivan and Miller, 1984). Similarly, slow contractions caused by proctolin in the coxal depressor muscle of the cockroach, Periplaneta americana, are associated with a $20 \%$ increase in input resistance (Adams and O'Shea, 1983). Also in the hyperneural muscle of Periplaneta americana, the induction of long-term contractions by proctolin is accompanied by only minimal depolarization but a $25 \%$ increase in input resistance. The latter is thought to reflect a decrease in $\mathrm{Ca}^{2+}$-activated $\mathrm{K}^{+}$currents (Hertel and Penzlin, 1986). These authors also proposed a scheme in which proctolin action involves cAMP-mediated protein phosphorylation of $\mathrm{K}^{+}$channels. Our results provide direct evidence for such a mechanism at the level of single $\mathrm{K}^{+}$channels.

\section{References}

Adams ME, O'Shea M (1983) Peptide cotransmitter at a neuromuscular junction. Science 221:286-289.

Baines RA, Downer RGH (1992) Comparative-studies on the mode of action of proctolin and phorbol-12,13-dibutyrate in their ability to contract the locust mandibular closer muscle. Arch Insect Biochem Physiol 20:215-229.

Baines RA, Lange AB, Downer RGH (1990) Proctolin in the innervation of the locust mandibular closer muscle modulates contractions through the elevation of inositol trisphosphate. J Comp Neurol 297: 479-486.

Bartos M, Allgäuer C, Eckert M, Honegger HW (1994) The antennal motor system of crickets: proctolin in slow and fast motoneurons as revealed by double labelling. Eur J Neurosci 6:825-836.

Bauer CK (1991) Modulatory action of proctolin in the locust (Locusta migratoria) antennal motor system. J Insect Physiol 37:663-673.

Belardetti F, Kandel ER, Siegelbaum SA (1987) Neuronal inhibition by the peptide FMRFamide involves opening of $\mathrm{S} \mathrm{K}^{+}$channels. Nature 325:153-156.

Beltz BS, Pontes M, Helluy SM, Kravitz EA (1990) Patterns of appearance of serotonin and proctolin immunoreactivities in the developing nervous system of the american lobster. J Neurobiol 21:521542.

Benson JA, Sullivan RE, Watson WH III, Augustine GJ (1981) The neuropeptide proctolin acts directly on Limulus cardiac muscle to increase the amplitude of contraction. Brain Res 213:449-454.

Bishop CA, Wine JJ, O'Shea M (1984) Neuropeptide proctolin in postural motoneurons of the crayfish. J Neurosci 4:2001-2009.

Bishop CA, Wine JJ, Nagy F, O'Shea MR (1987) Physiological consequences of a peptide cotransmitter in a crayfish nerve-muscle preparation. J Neurosci 7:1769-1779.

Bishop CA, Krouse ME, Wine JJ (1991a) Peptide cotransmitter potentiates calcium channel activity in crayfish skeletal muscle. J Neurosci 11:269-276.

Bishop CA, Krouse ME, Wine JJ (1991b) Peptide potentiation of calcium channel activity can be seasonally variable. J Exp Biol 156: $607-610$.

Brezina V, Eckert R, Erxleben C (1987) Modulation of potassium conductances by an endogenous neuropeptide in neurons of Aplysia californica. J Physiol (Lond) 382:267-290.

Brown BE (1967) Neuromuscular transmitter substance in insect visccral muscle. Science 155:595-596.

Cahalan MD, Chandy KG, DeCoursey TE, Gupta S (1985) A voltagegated potassium channel in human T lymphocytes. J Physiol (Lond) 358:197-237.

Colquhoun D, Sigworth FJ (1983) Fitting and statistical analysis of single-channel records. In: Single-channel recording (Sakmann B, Neher E, eds), pp 191-263. New York: Plenum.

Cook BJ, Holman GM (1980) Activation of potassium depolarized visceral muscles by proctolin and caffeine in the cockroach, Leucophaea maderae. Comp Biochem Physiol 67C:115-120.

Cook BJ, Holman GM (1985) The role of proctolin and glutamate in the excitation-contraction coupling of insect visceral muscle. Comp Biochem Physiol 80C:65-73.

De Wit RJW, Hekstra D, Jastorff B, Stec WJ, Baraniak J, Van Driel R, Van Haastert PJM (1984) Inhibitory action of certain cyclophosphate derivatives of cAMP on CAMP-dependent protein kinases. Eur J Biochem 142:255-260.
Eixleben C, Rathmayer W (1992) Modulation of a non voltage-dependent $\mathrm{K}^{+}$channel in crustacean muscle by proctolin. In: Proceedings of the 20th Göttingen Neurobiology Conference (Elsner N, Richter $D W$, eds), p 524. Stuttgart: G. Thieme.

Evans PD (1984) Studies on the mode of action of octopamine, 5-hydroxytryptamine and proctolin on the myogenic rhythm in the locust. J Exp Biol 110:231-251.

Fischer L, Florey E (1983) Modulation of synaptic transmission and excitation-contraction coupling in the opener muscle of the crayfish Astacus leptodactylus, by 5-hydroxytryptamine and octopamine. J Exp Biol 102:187-198.

Freschi JE (1989) Proctolin activates a slow, voltage-dependent sodium current in motoneurons of the lobster cardiac ganglion. Neurosci Lett 106:105-111.

Galler S, Rathmayer W (1992) Shortening velocity and force/ $\mathrm{p}_{\mathrm{C} \text {, }}$ relationship in skinned crab muscle fibres of different types. Pflügers Arch 420:187-193.

Golowasch J, Marder E (1992) Proctolin activates an inward current whose voltage dependence is modified by extracellular $\mathrm{Ca}^{2+}$. J Neurosci $12: 810-817$.

Goy MF, Schwarz TL, Kravitz EA (1984) Serotonin-induced protein phosphorylation in a lobster neuromuscular preparation. $\mathrm{J}$ Neurosci 4:611-626.

Hertel W, Penzlin H (1986) Electrophysiological studies of the effect of the neuropeptide proctolin on the hyperneural muscle of Periplaneta arnericana (L.). J Insect Physiol 32:239-248.

Hertel W, Pass G, Penzlin H (1985) Electrophysiological investigation of the antennal heart of Periplaneta americana and its reaction to proctolin. J Insect Physiol 31:563-572.

Irving SN, Miller TA (1980) Octopamine and proctolin mimic spontaneous membrane depolarisations in Lucilia larvae. Experientia 36: $566-568$

Jahromi SS, Atwood HL (1969) Correlation of structure, speed of contraction, and total tension in fast and slow abdominal muscle fibers of the lobster (Homarus americanus). J Exp Zool 171:25-38.

Kravitz EA, Glusman S, Harris-Warrick RM, Livingstone MS, Schwarz T, Goy MF (1980) Amines and a peptidc as ncurohormoncs in lobsters: actions on neuromuscular preparations and preliminary behavioural studies. J Exp Biol 89:159-175.

Kurachi Y (1985) Voltage-dependent activation of the inward-rectifier potassium channel in the ventricular cell membrane of guinea-pig heart. J Physiol (Lond) 366:365-385.

Marder E, Hooper SL, Siwicki KK (1986) Modulatory action and distribution of the neuropeptide proctolin in the crustacean stomatogastric nervous system. J Comp Neurol 243:454-467.

Mercier AJ, Wilkens JL (1985) Modulatory effects of proctolin on a crab ventilatory muscle. J Neurobiol 16:401-408.

Miller BA, Usherwood PNR (1990) Characteristics of five types of $\mathrm{K}^{+}$ channels in cultured locust muscle. J Exp Biol 154:45-65.

Murck H, Zittlau KE, Walther C (1989) Inactivation of a $\mathrm{K}^{+}$leakconductance in locust skeletal muscle by two neuropeptides: involvement of G-proteins. In: Proceedings of the 17th Göttingen Neurobiology Conference (Elsner N, Singer W, eds), p 433. Stuttgart: G. Thieme.

Nusbaum MP, Marder E (1989) A modulatory proctolin-containing neuron (MNP): II. State-dependent modulation of rhythmic motor activity. J Neurosci 9:1600-1607.

Orchard I, Belanger JH, Lange AB (1989) Proctolin: a review with emphasis on insects. J Neurobiol 20:470-496.

Pasztor VM, Golas LB (1993) The modulatory effects of serotonin, neuropeptide $F 1$ and proctolin on the receptor muscles of the lobster abdominal stretch receptor and their exoskeletal muscle homologues. J Exp Biol 174:363-374.

Piomelli D, Volterra A, Dale N, Siegelbaum SA, Kandel ER, Schwartz JH, Belardetti F (1987) Lipoxygenase metabolites of arachidonic acid as second messengers for presynaptic inhibition of Aplysia sensory cells. Nature 328:38-43.

Rane SG, Gerlach PH, Wyse GA (1984) Neuromuscular modulation in Limulus by both octopamine and proctolin. J Neurobiol 15:207-220.

Rathmayer W, Maier L (1987) Muscle fiber types in crabs: studies on single identified muscle fibers. Am Zool 27:1067-1077.

Schwarz TL, Harris-Warrick RM, Glusman S, Kravitz EA (1980) A peptide action in a lobster neuromuscular preparation. J Neurobiol 11:623-628.

Siegelbaum SA, Camardo JS, Kandel ER (1982) Serotonin and cyclic 
AMP close single $\mathrm{K}^{+}$channels in Aplysia sensory neurones. Nature 299:413-417.

Siwicki KK, Bishop CA (1986) Mapping of proctolin-like immunoreactivity in the central nervous system of lobster and crayfish. J Comp Neurol 243:435-453.

Siwicki KK, Beltz BS, Schwarz TZ, Kravitz EA (1985) Proctolin in the lobster nervous system. Peptides 6:393-402.

Stangier J, Dircksen H, Keller R (1986) Identification and immunocytochemical localization of proctolin in pericardial organs of the shore crab, Carcinus maenas. Peptides 7:67-72.

Swales LS, Evans PD (1988) Histochemical localization of octopamine- and proctolin-sensitive adenylate cyclase activity in a locust skeletal muscle. Histochemistry 90:233-239.

Watson WH III, Hoshi T (1985) Proctolin induces rhythmic contractions and spikes in Limulus heart muscle. Am J Physiol 249:R490R495.

Watson WH III, Augustine GJ, Benson JA, Sullivan RE (1983) Proctolin and an endogenous proctolin-like peptide enhance the contractility of the Limulus heart. J Exp Biol 103:55-73.

Witten J, O'Shea M (1985) Peptidergic innervation of insect muscle: immunochemical observations. J Comp Neurol 242:93-101.

Worden MK, Rahamimoff R, Kravitz EA (1993) Ion channel activity in lobster skeletal muscle membrane. J Exp Biol 182:113-130. 